\title{
Land molluscs from the Isola delle Femmine Nature Reserve (north-western Sicily, Italy) (Gastropoda Architaenioglossa Pulmonata)
}

\author{
Ignazio Sparacio', Salvatore Surdo ${ }^{2 *}$, Roberto Viviano ${ }^{3}$, Fabio Liberto ${ }^{4}$ \& Agatino Reitano ${ }^{5}$ \\ ${ }^{1}$ Via Principe di Paternò 3, 90144 Palermo, Italy; e-mail: edizionidanaus@gmail.com \\ ${ }^{2}$ Dipartimento di Scienze agrarie, alimentari e forestali, Viale delle Scienze Edificio 4, 90128 Palermo, Italy; e-mail: \\ salvatore.surdo@unipa.it Orcid: 0000-0002-0300-837X \\ ${ }^{3}$ Via Michele Cipolla 106, 90123 Palermo, Italy; e-mail: roberto.viviano@outlook.com \\ ${ }^{4}$ Via del Giubileo Magno 93, 90015 Cefalù, Italy; e-mail: fabioliberto@yahoo.it \\ ${ }^{5}$ Museo Civico di Storia Naturale, Via degli Studi 9, 97013 Comiso (Ragusa), Italy; e-mail: tinohawk@yahoo.it \\ ${ }^{*}$ Corresponding author
}

\begin{abstract}
The results of a study on the fauna of land molluscs from Isola delle Femmine Nature Reserve (NW Sicily, Italy) (Gastropoda Architaenioglossa Pulmonata) are here described. In this small island 23 species have been found, 6 of which are Sicilian endemic taxa. Siciliaria leucophryna microinsularis n. ssp. endemic to the Isola delle Femmine (or Isola di Fuori) is described. For each species ecological, distributional data and information on their presence on this island are provided.
\end{abstract}

KEY WORDS Conservation biology; micro-insularity; faunistic; land molluscs; Sicily.

Received 06.04.2020; accepted 03.06.2021; published online 04.08.2021

\section{INTRODUCTION}

The western Mediterranean Sea contains more than 1000 small islands, often less than $10 \mathrm{Km}^{2}$ wide. Some of them are poorly known or still to be explored. A lot of these host local endemics and have a more or less high biodiversity rate. In addition, they constitute a refuge area for many regional endemisms or threatened species of the neighbor areas like big islands or continental coast (see, for example, Lo Cascio \& Pasta, 2012; Muscarella \& Baragona, 2017; Lo Cascio \& Sciberras, 2020).

Small islands or archipelagos should play a significant role in conservation programs, and more investigations and deeper taxonomic knowledges are needed for this purpose (Minelli, 2012; Vela \& Pavon, 2012).

The aim of this work is to increase the knowledge on the living land molluscs of the Isola delle Femmine (or Isola di Fuori), a small island, on the north-western coast of Sicily (Italy).

Isola delle Femmine Nature Reserve was established under decree $\mathrm{n}^{\circ}$ 584, 01/09/1997 (Suppl. Ord. G.U.R.S. $n^{\circ} 3$ the $16 / 01 / 1998$ ) by Sicilian regional Government (Catalano et al., 1979) and managed by LIPU/Birdlife Italia.

This island is a part of the regional protected areas belonging to Nature 2000 network under European Direttives 79/409/CEE (Birds Directive) and 92/43/CEE ("Habitat" Dir.) as Site of Community Importance with code ITA020005 
(Isola delle Femmine). Afterwards, on the island was established a Geosite with decree D. Ass.R. Sicilia $n^{\circ} 106$ del 15 aprile 2015. Lastly, Isola delle Femmine was declared to be a Special Area of Conservation under European Direttive 92/43/CEE (Riggio \& Massa, 1974; Riggio \& Raimondo, 1992; Di Dio, 2011).

The reserve belongs the Municipality of Isola delle Femmine that adjoins Palermo (Sferracavallo) to the East and Capaci to the west. Due to its proximity to the coast the island has been the theater of many human activities, which ultimately resulted in a considerable environmental stress. Since Roman age a fish factory with an adjoining "tonnara" was operating on the island. On the highest point of the island ( $36 \mathrm{~m}$ above sea level) there is a XVI sec. sighting tower, called "Torre di Fuori" (Figs. 7, 8) opposed to the "Torre di Terra" building on the mainland (La Rocca, 2004). The tower, as we can see it, was commissioned by viceroy Marco Antonio Colonna to the military Tuscan architects and engineers Tiburzio Spannocchi and Camillo Camilliani (Mazzarella \& Zanca, 1985; Maurici \& Lucido, 2008).

Until 1997, year of estabilishment of the reserve, herding was practiced. During autumn sheep and goats were transported by boats, while cows and horses came swimming and left to graze on the island until spring. Other human-caused environmental disturbances were the practice of cutting trees to obtain lumber, the harvesting of dwarf palm leaves (Chamaerops humilis L.) for the artisanal manifacture of brooms, fires started to stimulate grass renewal and harvest of edible land snails.

The wild rabbit, Oryctolagus cuniculus (Linnaeus, 1758), was introduced to the island for hunting purposes. Later the colonization by Norway rat, Rattus norvegicus (Berkenhout, 1769) took place. Currently, on the island there is a Yellowlegged Gull Larus michahellis (Naumann, 1840) nesting colony.

As part of numerous research projects on flora and fauna of the islet untertaken by the managing body of the reserve, a study on land snails and slugs has been carried out since 2002. The work, intensified over the last year, has allowed us to achieve a good knowledge on the diversity and consistency of these populations, subject of this work.

\section{MATERIAL AND METHODS}

\section{Study area}

Geographical and geological setting. Isola delle Femmine $\left(38^{\circ} 12^{\prime} 36^{\prime \prime N ~} 13^{\circ} 14^{\prime} 10^{\prime \prime} \mathrm{E}\right)$ is located to the northwest of Sicily, near Palermo, along a stretch of coast between Capo Gallo and Punta Raisi, in the Gulf of Carini. A 2 meter deep and 400 meter long arm of sea separates the island from the mainland (Figs. 1-6).

The islet covers an area of about 14 hectares and has an almost oval shape. Its major axis, NW-SE oriented, is $575 \mathrm{~m}$ long, its maximum width $325 \mathrm{~m}$, and the highest point reaches $36.80 \mathrm{~m}$ asl where an ancient tower was built.

Three slopes start from the peak of the island and face south-east, south-west and north, respectively. The former extends for 300 meters and gently descends from an altitude of 35 meters, down to the sea level, with an almost flat course in the last stretch. This side is the least exposed to the action of both winds and washout. The south-west side is narrower and characterized by a steeper slope and greater outcrops of rock. Finally, the north side, very steep and rugged, consist mainly of sheer rocks and appears to the most exposed to the action of the winds and sea erosion. There are no freshwater springs on the island.

The study area is part of the ApennineMaghrebian chain (Grasso, 2001) and consist of a deformed rocky substrate of the Mesozoic-Tertiary age and a Plio-Pleistocene coverage of clastic deposits. Such a rocky substrate is the extension into the sea of the panormid soils emerging in the hinterland and consists of limestone and dolomitic limestone of the Upper Jurassic-Lower Cretaceous age (Catalano et al., 2013a, b).

The study area belongs to the Palermo Mountains, a sector of the emerged Sicilian FTB (Sicilian Fold and Thrust Belt) that is a segment of the Apennine-Tyrrhenian System and whose building up refers to both the post-collisional convergence between Africa and the complex "European" crust (Bonardi et al., 2003) and the coeval roll-back of the subduction hinge of the Adriatic Ionian-African lithosphere (Doglioni et al., 1999; Catalano et al., 2013a, b). The tectonic edifice is therefore the result of the piling up of deep-water units and carbonate platforms 
(Imerese and Panormide: Catalano et al., 2013b). Such tectonic units settled after the lower Miocene (Abate et al., 1978) while the carbonate rocks, described above, are the basements of the Plio-Pleistocene deposits visible in the coastal strip.

About 19,000 years ago, maximum of the regressive phase of the Wurmian glaciations brought the sea level $120 \mathrm{~m}$ below the current value (Segre, 1969; Ulzega et al., 1980). Subsequently, approximately 5,000 years ago, the positive change in sea level happening during the so-called Versilian "transgression" caused the sea level to rise to current altitudes with a maximum of about $2 \mathrm{~m}$ (Segre, 1969; Ulzega \& Ozer, 1982).

Climatic considerations. The average annual rainfall in the area amounts to $632 \mathrm{~mm}$ and it is mainly concentrated in the autumn-winter seasons, while the average annual temperature is $19.6{ }^{\circ} \mathrm{C}$ as recorded by a thermo pluviometric station located in the village of Isola delle Femmine (4 m above sea level) (Duro et al., 1996). The bioclimatic indices derived from the thermopluviometric data show a Mediterranean-type macrobioclimate with an oceanic rain-seasonal bioclimate (Rivas-Martínez, 2008). The same indexes, in particular, determined an upper thermo-Mediterranean thermotype and lower dry ombrotype, respectively.

The flora of the island. According to the last census (Caldarella et al., 2010), the vegetation of Isola delle Femmine includes 219 infraspecific taxa. Of these, 105 were confirmed with respect to the previous census (Di Martino \& Di Trapani, 1964). Present life-form spectrum puts in evidence the prevalence of therophytes (ca. 62\%), followed by hemicryptophytes (ca. 20\%), geophytes (ca. 9\%), chamaephytes $(5.5 \%)$, nanophanerophytes $(2.3 \%)$ and phanerophytes (1.8\%). As concerns chorogical spectra, the Mediterranean element still is the most common (ca. 33\%), while endemic and subendemic elements are very poorly represented (6 taxa, i.e. $2.7 \%$ of the local vascular flora).

The primary landscape in the central sector of the island consists of Mediterranean maquis that moving towards the coastline progressively turn in belts of halophilic and halonitrophil vegetation (Figs. 9, 10). The dynamism of the vegetation is slowed down by the extreme environmental conditions, partly exacerbated by the poor soil evolution and by the high levels of sodium chloride in the upmost portion of the soil and originating from marine aerosol deposition (Caldarella et al., 2010).

Currently the flora of the island appears to be dominated by Malva spp., Pistacia lentiscus L., and Pennisetum setaceum (Forssk.) Chiov.

The fauna of the island. After the eradication of the European rabbit Oryctolagus cuniculus and of the Norway Rat Rattus norvegicus (Canale et al., 2019), the vertebrate fauna mainly reduced to few species of nesting birds including a colony (about 500 pairs) of the Yellow-legged Gull Larus michahellis Naumann, 1840 (Massa et al., 2021); the Sardinian warbler, Sylvia melanocephala (J.F. Gmelin, 1789); the Blackbird Turdus merula Linnaeus, 1758, the Zitting Cisticola Cisticola juncidis (Rafinesque, 1810), the latter nesting discontinuously only (LIPU, 2009, 2011).

Furthermore it is worth to mention the occasional nesting (in the 2003 and 2004) of the Jackdaw Corvus monedula (Linnaeus, 1758) (LIPU, 2003, 2004) and an attempt of nesting in the last few years by the Raven Corvus corax (Linnaeus, 1758).

The reptiles are present on the island with five species: Hierophis viridiflavus carbonarius (Lacépède, 1789), Chalcides ocellatus (Forsskål, 1775), Podarcis siculus Rafinesque, 1810, Tarentola mauritanica (Linnaeus, 1758), and Hemidactylus turcicus (Linnaeus, 1758) (LIPU, 1999, 2004).

Very little is known about invertebrate fauna (Carapezza, 2006) also because in the entomological collections of the past it is not clear whether the labeling "Isola delle Femmine" refers to the islet or the stretch of coast where the homonymous town stands (Aliquò, 1996).

Our ongoing studies are focused on invertebrate fauna as it turns out to be significantly rich and diversified.

\section{Methods}

Ecological observations on land molluscs were performed directly in the nature reserve and allowed discovering of living specimens and shells suitable for the subsequent morphological and taxonomic classifications. Two sampling methods were employed, namely visual recovery and 

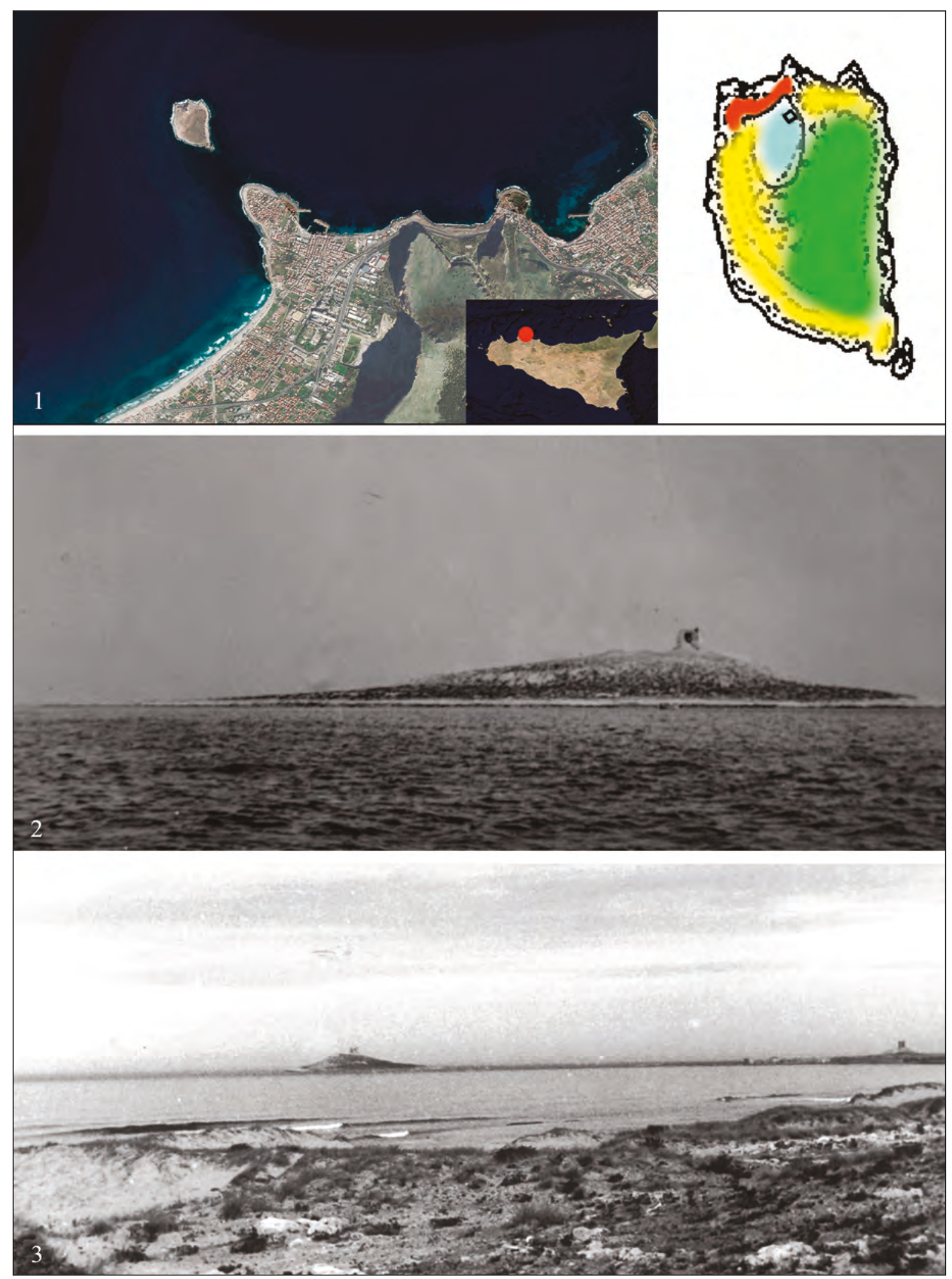

Figure 1. Isola delle Femmine Nature Reserve (NW-Sicily, Italy); on the right, in yellow: open areas with rocks and vegetation, green: Pistacia lentiscus maquis, red: rocky walls, light blue: ruderal area. Figure 2. Isola delle Femmine, 1950, photo by T. De Stefani. Figure 3. Isola delle Femmine and Torre di Terra seen from the Capaci dunes, 21.XII.1958, photo by F.P. Romano. 

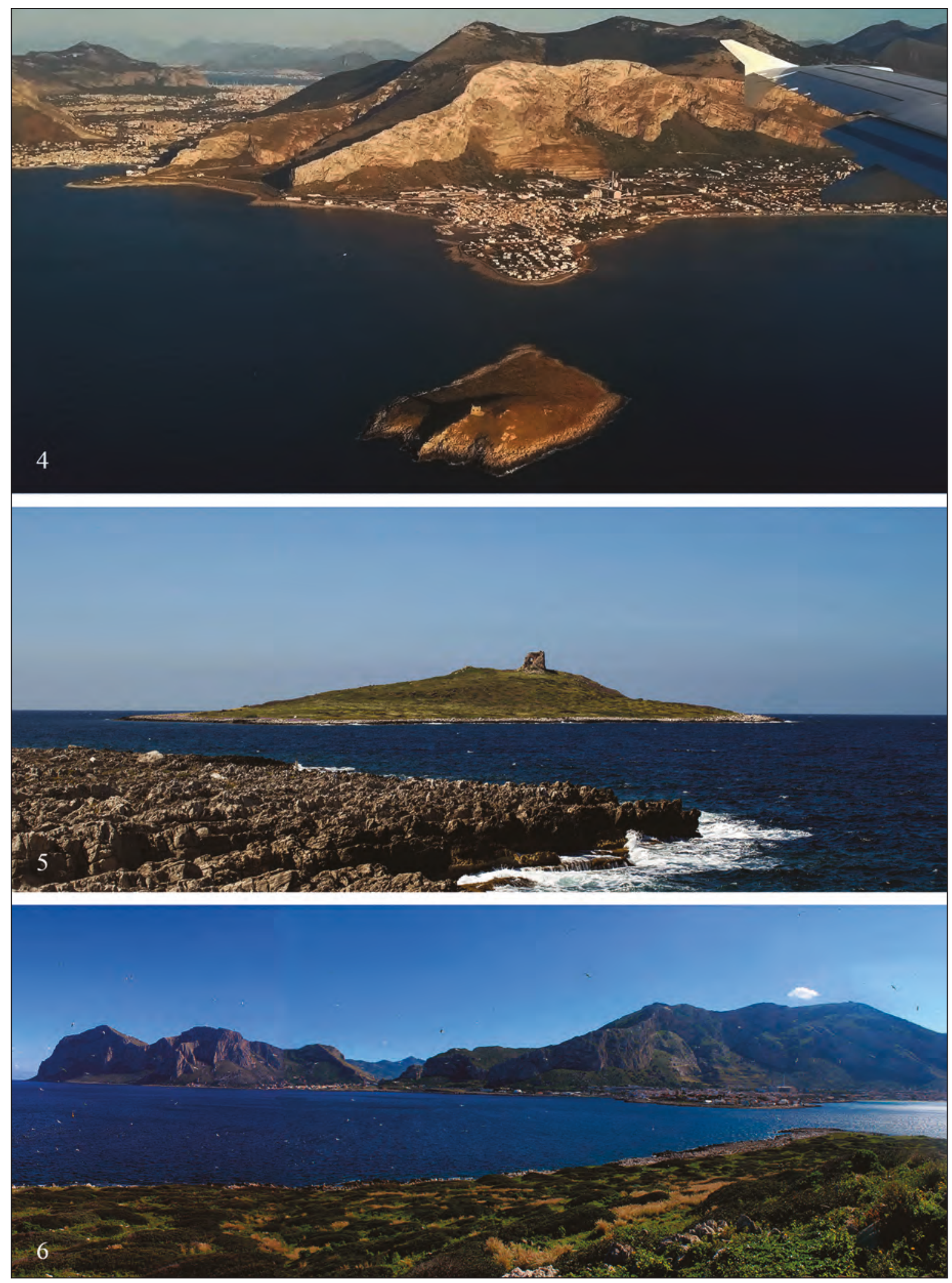

Figure 4. Isola delle Femmine and neighboring coast, aerial view, 2020 (photo by A. Barbera). Figure 5. Isola delle Femmine (Sicily, Italy). Figure 6. Capo Gallo, Sferracavallo and Isola delle Femmine seen from the southern side of the Isola delle Femmine (from left to right). 

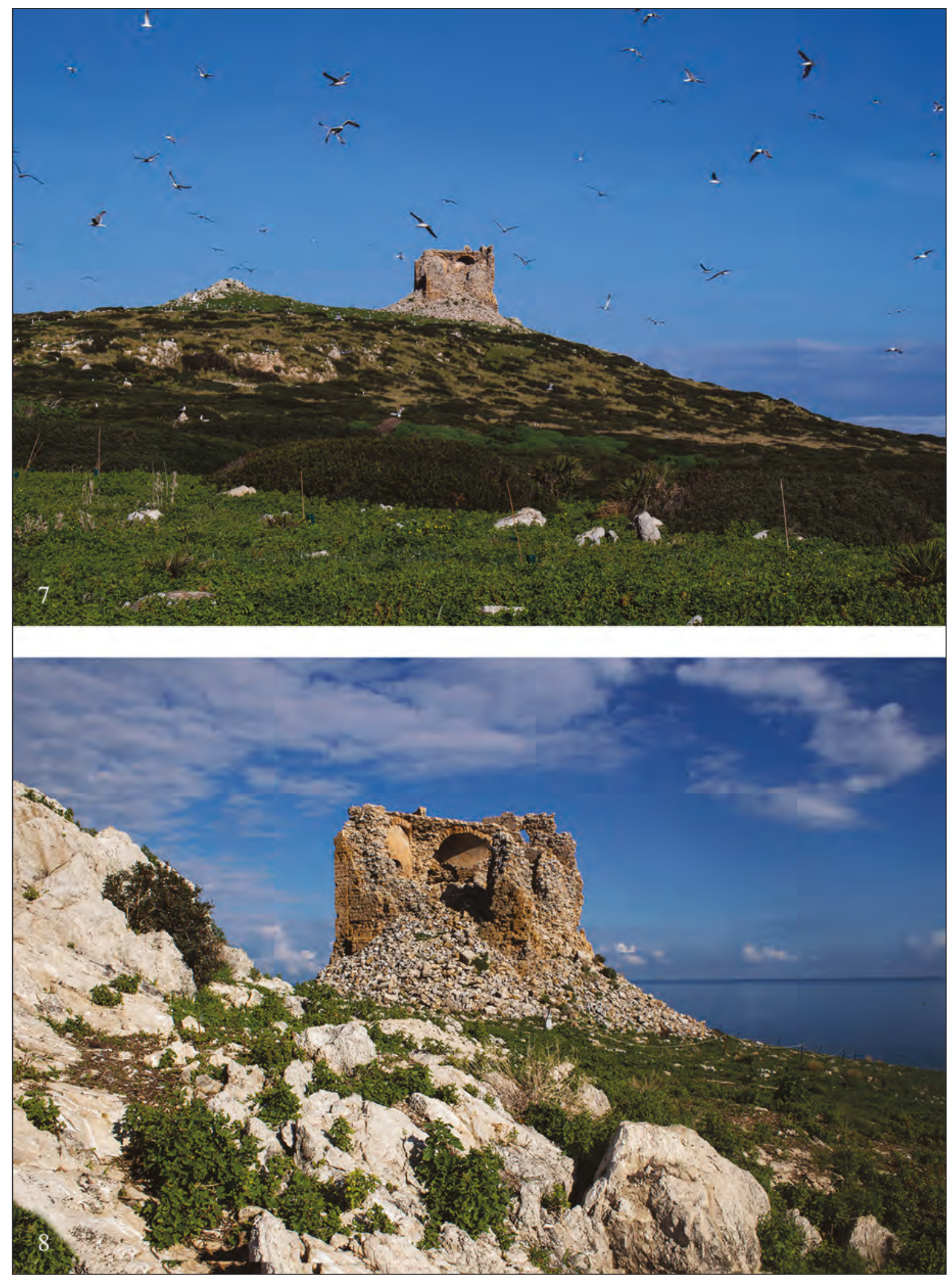

Figure 7. Isola delle Femmine, southern slope and the Torre di Fuori in the highest part of the territory. Figure 8. Isola delle Femmine, Torre di Fuori. 

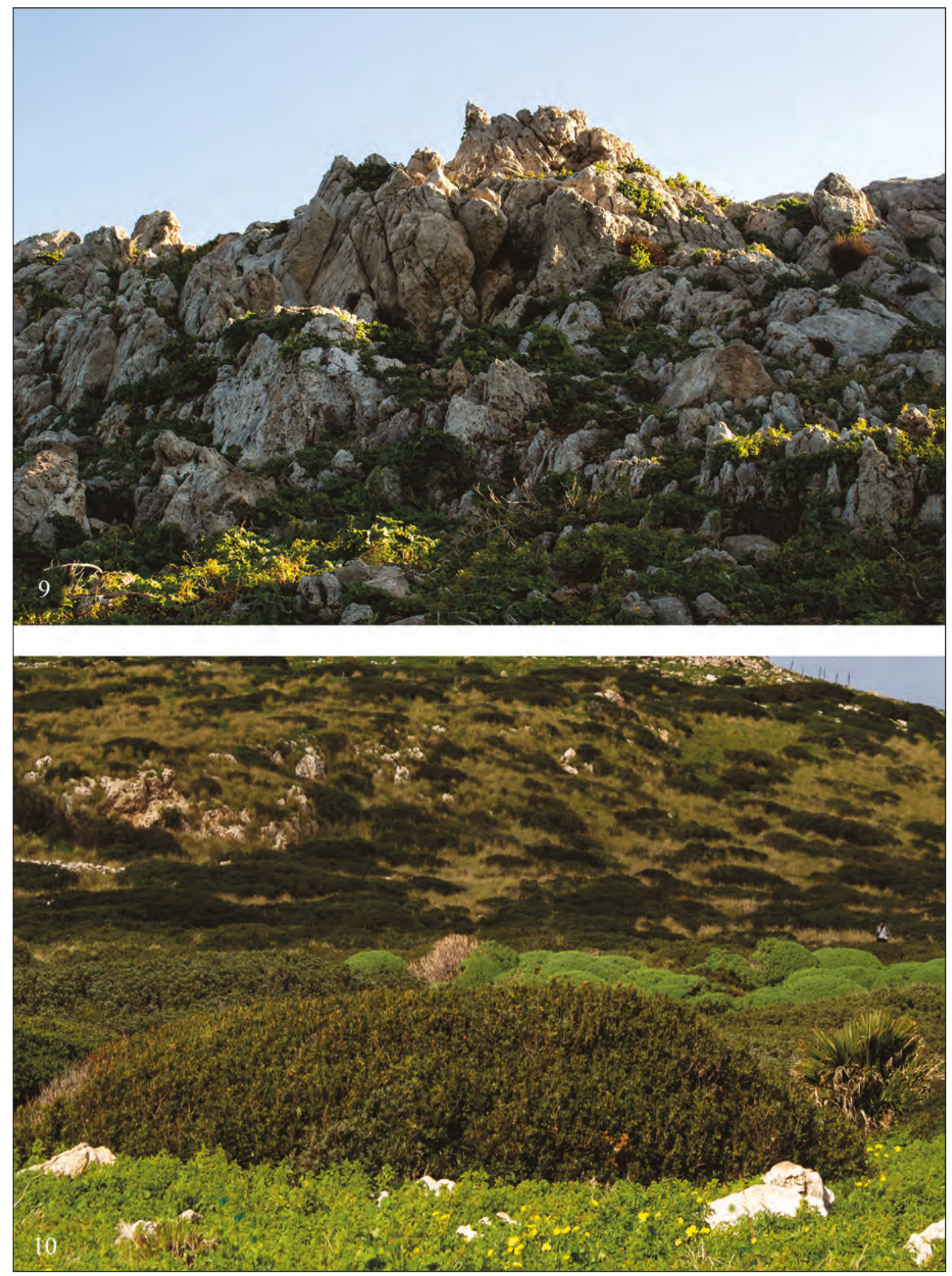

Figure 9. Isola delle Femmine, limestone rocks on the northern slope. Figure 10. Isola delle Femmine: Pistacia lentiscus, Euphorbia dendroides and Chamaerops humilis on the southern slope. 
sieving of debris. For the visual collection, a careful search was carried out throughout the island and in all possible microhabitats. Animals and shells were then collected from limestone rocks, the walls of the Torre di Fuori, the ground, under large and small stones naturally lying on the ground, and under organic remains such as decaying either organic plants or natural animals, near seagull nests, mastic litter. The aim of the research was to find species with different ecological requirements. The species were classified in laboratory through the morphological analysis of the shell and genitals with the aid of an Optika stereomicroscope. Height and maximum diameter of the shell along with some parts of genitalia were measured (in millimeters) by a digital gauge. The photos were taken with a Canon EOS 100D camera. Some specimens were fixed in $80 \%$ ethanol and the reproductive system was extracted using a scalpel, scissors and needles. Taxonomic references are mainly based on MolluscaBase (2021) and other cited bibliographical references. Chorological categories are based on La Greca (1962) subsequently elaborated by Vigna Taglianti et al. $(1993,1999)$ and Parenzan (1994).

Biological and ecological data are reported for all species. The materials used for this study were preserved in the following Museums and private collections: F. Liberto, Cefalù, Italy (CL); Museo Civico di Storia Naturale di Genova "G. Doria", Italy (MSNG); Museo Civico di Zoologia, Rome, Italy (MCZR); Muséum d'Histoire Naturelle de Genève, Switzerland (MHNG); Natural History Museum University of Florence Zoological Section "La Specola", Florence, Italy (MZUF); A. Reitano, Catania, Italy (CR); I. Sparacio, Palermo, Italy (CS), R. Viviano, Palermo, Italy (CV).

ABBREVIATIONS AND ACRONYMS. A: atrium; AP1: distal annular pad; AP2: proximal annular pad; AUPP: anterior upper palatal plica; $\mathrm{BC}$ : bursa copulatrix; CD: copulatory duct; $\mathrm{CL}$ : columellar lamella; DBC: diverticulum of the bursa copulatrix; E: epiphallus; ELP: epiphallar longitudinal pleats; FO: free oviduct; G: penial pseudopapilla; IPP: inner penial pleats; L: lunella; P: penis; PL: parietal lamella; PP: principal plica; PR: penial retractor muscle; PUPP: posterior upper palatal plica; SCL: subcolumellar lamella; SL: spiral lamella; SP: sutural plica; UOS: uterine ovispermiduct; V: vagina; VD: vas deferens. D: shell maximum diameter; ex/x: specimen/s; H: shell height; HA: aperture width; leg.: legit; m: meter/s; mm: millimeter/s; R2: ribs number on 2 $\mathrm{mm}$ of the penultimate whorl; sh: shell/s; WA: aperture height.

\section{RESULTS}

\section{Systematics}

Classis GASTROPODA Cuvier, 1791

Ordo LITTORINIMORPHA Pchelintsev, 1963

Familia POMATIIDAE Newton, 1891

\section{Tudorella panormitana (Sacchi, 1954)}

Distribution and Biology. Endemic species of the Palermo Mountains, widespread from Trabia in the west to Monte Palmeto in the east (Sacchi, 1954; Alzona, 1971; Lo Brano \& Sparacio, 2006; Reitano et al., 2012). This species was reported for the Isola delle Femmine by Sacchi (1954).

Tudorella panormitana is a xeroresistent species typical of limestone soil.

Status and CONSERVATION. Tudorella panormitana is Least Concern according to the Categories and Criteria of the IUCN Red List of Threatened Species (IUCN, 2017; Martínez-Ortí, 2017; Neubert et al., 2019).

StUdy AREA. The live specimens were mainly found at the base of the rocks on the northern slope; the shells were found in garrigue areas and in the Pistacia lentiscus litter (Figs. 11, 12, 31).

Remarks. According to Pfenninger et al. (2010), seems that the current distribution of Tudorella Fischer, 1885 in the Western Mediterranean is due to the fragmentation of the original distribution area that occurred in the late Oligocene and Miocene, and dispersive phenomena that occurred in the late Miocene and Pleistocene. The molecular study of Pfenninger et al. (2010) also highlights the existence of relevant genetic distances between populations of T. panormitana and T. multisulcata (Potiez et Michaud, 1838) species widespread in the mountains of Trapani and southern Sicily. 
Infraclassis PULMONATA Cuvier in Blanville, 1824 Ordo STYLOMMATOPHORA A. Schmidt, 1855 Familia CHONDRINIDAE Steenberg, 1925

\section{Granopupa granum (Draparnaud, 1801)}

Distribution AND Biology. EuropeanMediterranean-Turanian, present throughout Italy.

Xeroresistant and calciphilous species, usually found in rocky and ruderal environments. Common in Sicily in arid areas and Mediterranean scrub.

Status and CONSERVATion. Least Concern (Cuttelod et al., 2011; Neubert et al., 2019).

StUdy AREA. A few shells of G. granum were found in detritus at the base of outcropping rocks exposed to south-east and partly covered by Pistacia lentiscus and Pennisetum setaceum.

Familia TRUNCATELLINIDAE Steenberg, 1925

\section{Truncatellina callicratis (Scacchi, 1833)}

Distribution AND Biology. EuropeanMediterranean-Turanian species, widely distributed in the Mediterranean region.

It is common in dry limestone landscapes with herbaceous vegetation and Mediterranean maquis.

Status AND CONSERVATION. Least Concern (Cuttelod et al., 2011; Neubert et al., 2019).

STUDY AREA. Living specimens of T. callicratis have been found only in the Pistacia lentiscus litter (Figs. 13, 14, 32).

Familia ENIDAE B.B. Woodward, 1903

Mastus pupa (Linnaeus, 1758)

Distribution AND Biology. Mediterranean. Mastus pupa is present in Southern Italy, Sardinia and Sicily (Alzona, 1971; Beckmann, 1990; Manganelli et al., 1995).

It is a thermophilic species, present in a wide variety of habitats.

Status and CONSERVATion. Least Concern (Cuttelod et al., 2011; Neubert et al., 2019).

Study AREA. This specie is common in the
Reserve (Figs. 15, 16, 33). It is more commonly found, both alive and shells, in the south-east slope between the scrub of Pistacia lentiscus and Pennisetum setaceum, in the litter and under boulders. Also present around the Torre di Fuori and at the base of more exposed rocky outcrops.

Familia FERUSSACIIDAE Bourguignat, 1883

Cecilioides (Cecilioides) raphidia sicula Beckmann et Falkner, 2008

Distribution And Biology. Cecilioides (Cecilioides) raphidia raphidia (Bourguignat, 1856) lives in North-Africa, C. raphidia sicula is an endemic subspecies of Sicily (Beckmann \& Falkner, 2008).

Status and COnServation. Least Concern (Neubert et al., 2019).

STUDY AREA. Very common with empty shells in the debris found under stones, in crevices, and above all, in the Pistacia lentiscus litter (Fig. 34).

Remarks. The genus Cecilioides A. Férussac, 1814 comprises endogenous species that usually live buried under stones, between plant roots and on the soil of caves. Beckmann \& Falkner (2008) report for the surroundings of Palermo also $C$. actoniana (Benoit, 1862) and C. rizzeana (Benoit, 1862).

\section{Ferussacia folliculum (Schröter, 1874)}

Distribution AND Biology. Mediterranean. Thermophilic species, inhabiting arid environments with little vegetation cover.

Status and CONSERvation. Least Concern (Neubert et al., 2019).

STUDY AREA. In the Reserve, F. folliculum is very common; both living specimens and empty shells were found under rocks or debris (Figs. 17, 35).

Familia ACHATINIDAE Swainson, 1840

Rumina decollata (Linnaeus, 1758)

Distribution AND Biology. Mediterranean; it is 
present throughout the Italian peninsula and the islands. It was accidentally introduced by human activities in many temperate regions. In CentralNorthern America to it was employed in biological control against the helicid Cornu aspersum (Cowie, 2001).

Rumina decollata is thermophilic and xeroresistant thanks to the secretions of a calcium carbonate epiphragm to close the aperture against body-water evaporation while allowing gas exchange and its habit of burrowing into the ground during the hot season. Its ability to self-fertilization and the eggs with a calcareus casing have contributed to its wide spread. It is omnivorous and even necrophilic. It frequently lives under stones, among organic debris, in dry stone walls and under dead trunks, bushes and shrubs.

Status and CONSERVATion. Least Concern (Neubert et al., 2019).

StUdy AREA. It is quite common, especially around the Torre di Fuori and along the path, even on the Pistacia lentiscus litter where it has also been found alive (Figs. 18, 36).

Remarks. The genus Rumina Risso, 1826 is represented in Sicily with two species: $R$. saharica Pallary, 1901 from Marettimo island (Liberto et al., 2012) and $R$. decollata, widespread throughout the island. Rumina decollata is also present in almost all the circumsicilian islands (Monterosato, 1892).

DNA-sequence data have suggested that $R$. decollata is a clomplex of at least seven cryptic phylogenetic species (Prévot et al., 2014) but further studies on a larger number of populations would be needed.

Familia CLAUSILIIDAE J.E. Gray, 1855

Siciliaria leucophryna microinsularis n. ssp. https://zoobank.org:act:010DF2E8-A051-4F7DBC2C-5B63CE8C3BA9

TyPE MATERIAL. Holotype, Isola delle Femmine (small island near Municipality of Isola delle Femmine, Palermo, Italy), 18.V.2002, leg. I. Sparacio (MCZR) (Fig. 37). Paratypes, all from the type locality: 18.V.2002, 5 exx, leg. I. Sparacio (CS5803/5); 3.V.2010, 2 exx, leg. I. Sparacio (CS5-804/2); 22.XII.2020, 24 exx., leg. I. Sparacio (CS-5805/24); idem, 38 exx, leg. R. Viviano (CV); idem, 5 exx., leg. I. Sparacio \& R. Viviano (CL19446-19450); idem, 5 exx., leg. I. Sparacio \& R. Viviano (CR); idem, 2 exx., leg. I. Sparacio \& R. Viviano (MSNG); idem, 2 exx., leg. I. Sparacio \& R. Viviano (MZUF); idem, 2 exx., leg. I. Sparacio \& R. Viviano (MHNG); 18.II.2021, 7 exx., leg. I. Sparacio (CS-5806/7, Figs. 38-44); idem, 9 exx, leg. R. Viviano (CV); idem, 2 exx, leg. S. Surdo (CS5807/2); 01.IV.2021, 10 exx., leg. I. Sparacio (CS-5808/10); idem, 6 exx, leg. R. Viviano \& S. Surdo (CV); 27.V.2021, 12 exx, leg. R. Viviano (CV), 1 ex, leg A. Viviano \& S. Surdo (CV).

DESCRIPTION OF THE SHELl. Sinistral, fusiform, yellowish, usually decollated with 7-9 slightly convex whorls and robuste, spaced and slightly oblique ribs (Figs. 21, 37); these are irregularly arranged in the cervical portion of the last whorl; R2: 4; H: 14-18 mm; D: 4-5.1 mm; HA: 5-5.15 mm; WA: $3.85-3.9 \mathrm{~mm}$; sutures deep, closed umbilicus; basal keel very distinct and revelated; dorsal keel obsolete; rounded aperture, reflected peristome not detached above. Apical whorls, observed only in one damaged specimen (Fig. 40), almost cylindrical: first whorl with smooth surface, second whorl with very fine punctures and very minute and just raised ribs.

On palatum (Fig. 38) there are: a thin sutural plica, the principal plica long and well developed, its internal side protrudes slightly beyond the lunella, upper palatal plica divided into an anterior portion running parallel to principal plica and widely separated from a posterior portion fused to apical end of lunella. Lunella dorso-lateral.

On parietum (Fig. 39) starting from the suture, there are: a parietal lamella that surpasses the spiral lamella, this latter progressively decreasing in height towards the aperture, columellar lamella low, subcolumellar lamella internal, not visible in frontal view. Clausilium (Fig. 41) plough-like with sub-rectangular basal plate, emarginated, rounded sutural angle and straight columellar edge, distal part with an evident incision.

Genitalia (Figs. 42-44). Vagina (3-3.2 mm) longer than the free oviduct $(2.8 \mathrm{~mm})$, bursa copulatrix with a robust copulatory duct (3.3-3.45 $\mathrm{mm}$ ) shorter than the bursa copulatrix complex (3.1$3.2 \mathrm{~mm}$ ); bursa copulatrix is oval-elongated, pointed at the apex; diverticulum of the bursa copulatrix (6$6.3 \mathrm{~mm}$ ) longer than bursa copulatrix complex; vas deferent long and slender, entering the apical portion 
of epiphallus; epiphallus $(4-4.3 \mathrm{~mm})$ divided by point of insertion of robust penial retractor muscle into sub-rectangular distal portion, and elongated proximal portion with an evident epiphallar ring where start the penis; penis $(2.9-3.2 \mathrm{~mm})$ wider than epiphallus, sub-cylindrical in shape.

In the inner genitalia, the penis shows two longitudinal raised pleats that occupy almost the whole penial lumen; penial pseudopapilla is elongated (almost $1 / 3$ of the total length of penis) with some thin longitudinal grooves on its surface. The penis-epiphallus transition shows a first distal annular pad and a second proximal annular pad from which the penial pseudopapilla and the epiphallar pleats originate. Inner wall of the vagina with irregular and little transverse-oblique pleats in the prossimal portion, and with very thin and irregular thin longitudinal pleats in the distal portion.

Body. Animal yellow-brown; skin tubercles oval-elongated browner than the body; upper tentacles rather short, cylindro-conical, with black eyes; foot with sole paler than body (Fig. 22).

Distribution AND Biology. Siciliaria leucophryna leucophryna (L. Pfeiffer, 1862) is a calciphilous species endemic of Sicily; it is limited to the surroundings of Palermo (Sferracavallo) to the East and Municipality of Isola delle Femmine to the West. Siciliaria leucophryna microinsularis n. ssp. lives only on some calcareous rocks of the island of Isola delle Femmine; several specimens was found also in the Pistacia lentiscus litter.

ETymology. The name of this new subspecies derives from the locality where it lives: a small territory on a small island (Isola delle Femmine or Isola di Fuori).

Status AND CONSERVATION. Siciliaria leucophryna leucophryna is Endangered species according to De Mattia (2017) and Neubert et al. (2019). Siciliaria leucophryna microinsularis $\mathrm{n}$. ssp. must be classified as Critically Endangered (CR) due to the very restricted area in which it lives.

OtheR EXAMINED MATERIAL. Siciliaria leucophryna leucophryna: Italy, Sicily, Palermo, Sferracavallo: Grotta Conza, 18.I.1981, 6 exx, leg. I. Sparacio (CS-5801/6); idem, 36, exx, 11.IX.2003 (CS5802/36); idem, 3 exx, 27.V.2012, leg. R. Viviano (CV); idem, 35 exx, 20.VII.2005, leg. A. Reitano (CR); idem, 12 exx, 5.XII.2008, leg. A. Reitano (CR); idem, 38 11'14'N, 13¹6’39'”, 200 m, 27.V.2012, 3 exx, 6 shells (CL 11736-11744); idem, 245 m, legit Viviano R., 16.X.2016, 3 exx (CL 17308-17310);

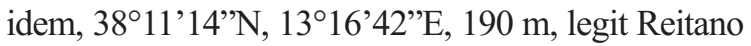
A., 2011, 6 exx, 8 shells (CL 17365-17391).

Comparative notes. Siciliaria leucophryna has been confused with $S$. eminens (Schmidt, 1868), particularly by Boettger (1879) and Benoit (1882), however Nordsieck (2002) specified its distribution area in the neighbourhoods of Sferracavallo and selected a lectotype (Senckenberg Museum, Frankfurt 67478, coll. O. Boettger ex-Dohrn ex-L. Pfeiffer) (see also Reitano et al., 2012).

Siciliaria leucophryna microinsularis $\mathrm{n}$. ssp. is morphologically different from topotypical specimens of $S$. leucophryna leucophryna (Sferracavallo, Grotta Conza) due to its smaller size (H: 18-22 $\mathrm{mm}$ in $S$. leucophryna), lighter color, anterior upper palatal plica widely separated from posterior upper palatal plica (little separated or connected in S. leucophryna leucophryna), first duct of the bursa copulatrix shorter than in $S$. leucophryna leucophryna), penial pseudopapilla longer and inner walls of the vagina with transverseoblique pleats and some very thin longitudinal pleats in the distal portion (only transverse-oblique pleats in S. leucophryna leucophryna).

\section{Familia PRISTILOMATIDAE Cockerell, 1891}

Vitrea subrimata (Reinhardt, 1871)

Distribution And Biology. Species with European-Mediterranean distribution spreading throughout Italy. Vitrea subrimata comprises a complex of populations which differ by the structure of flabelliform appendices of the inner wall of the proximal penis and therefore needing a modern revision (Manganelli et al., 1995; Ferreri et al., 2005).

Vitrea subrimata inhabits mainly natural environments, usually cavities in soil, or under partly concealed rocks or boulders.

Status and Conservation. Least Concern (Neubert et al., 2019).

STUDY AREA. Only empty shells of $V$. subrimata were found by sieving debris collected under stones, in crevices, and above all, in the Pistacia lentiscus litter (Fig. 45). 
Familia AGRIOLIMACIDAE H. Wagner, 1935

Deroceras panormitanum (Lessona et Pollonera, 1882)

Distribution AND Biology. EuropeanMediterranean and some extra-European countries. A common and widespread species, anthropophilic and ubiquitous.

D. panormitanum is very common in Sicily, where it lives in a wide range of natural and anthropized environments.

Status and CONSERVATION. Least Concern (Rowson, 2017; Neubert et al., 2019).

STUDY AREA. Living specimens of this species were found mainly on the north side of the island and around Torre di Fuori, under stones (Figs. 19, 20 ), and on the east side some limacella were collected by sieving the soil.

REMARKS. Deroceras panormitanum is considered a species variable in external colour, morphology and shape of the genitalia (Giusti, 1973; 1976; Giusti \& Manganelli, 1990; Giusti et al., 1995; Wiktor, 2000; Reise et al., 2011).

Familia TRISSEXODONTIDAE H. Nordsieck, 1987

Caracollina (Caracollina) lenticula (Michaud, 1831)

Distribution AND Biology. Mediterranean distribution. In Sicily, it is very common from a few meters above sea level up to medium altitudes, under stones, in the dune system and in the compact hilly terrain.

Status and CONSERVation. Least Concern (Cuttelod et al., 2011; Neubert et al., 2019).

Study AREA. Caracollina lenticula, together with Eobania vermiculata (O.F. Müller, 1774) and Ferussacia folliculum, is one of the most frequent species on the island (Fig. 23, 24, 46). Living specimens and empty shells of C. lenticula were found in the Pistacia lentiscus litter and under stones.

Familia GEOMITRIDAE C.R. Boettger, 1909
Cochlicella acuta (O.F. Müller, 1774)

Distribution AND Biology. Mediterranean. It is reported for almost all regions of central-southern Italy, Sicily and Sardinia (Alzona, 1971; Cossignani \& Cossignani, 1995, 2020; Manganelli et al., 1995).

In Sicily, it is very common from a few meters above sea level up to medium altitudes.

Status and CONSERvation. Least Concern (Cuttelod et al., 2011; Neubert et al., 2019).

StUdy AREA. During these investigations, only one living young specimen was found among the boulders positioned below the reserve billboard.

Xerotricha conspurcata (Draparnaud, 1801)

Distribution AND Biology. Mediterranean, reported in Italy for peninsular regions, Sicily and Sardinia (Alzona, 1971; Cossignani \& Cossignani, 1995, 2020; Manganelli et al., 1995).

It is very common in Sicily under stones and debris from various coastal areas to medium altitudes. It lives in natural or antropized environments.

Status and Conservation. Least Concern (Cuttelod et al., 2011; Neubert et al., 2019).

StUdy AREA. In the Reserve, it is a common species, especially around the Torre di Fuori, where it lives in the macerate and under vegetal detritus, and in the litter of Pistacia lentiscus and Pennisetum setaceum (Figs. 25, 26, 47).

Xerotricha apicina (Lamarck, 1822)

Distribution AND Biology. Mediterranean distribution, reported in Italy along the Tyrrhenian, southern and island regions (Alzona, 1971; Cossignani \& Cossignani, 1995, 2020; Manganelli et al., 1995).

This species is very common in Sicily under stones and debris from coastal areas to medium altitudes, in natural or antropized environments.

Status and COnSERvation. Least Concern (Cuttelod et al., 2011; Neubert et al., 2019).

STUDY AREA. Numerous shells were collected only in the surroundings of Torre di Fuori, under limestone boulders, in the soil and under the leaf 
blades of prostrate herbaceous plants. Only one living specimen was found in the soil at the base of outcropping rocks. Towards the end of May they estivate burying themselves and closing the aperture with a thin white, paper-like epiphragm (Fig. 27).

Cernuella (Cernuella) cfr. cisalpina (Rossmässler, 1837)

Distribution AND Biology. EuropeanMediterranean distribution (Manganelli \& Giusti, 1987; Manganelli et al., 1995).

In Sicily, this species is common, from back dunes up to medium altitudes, in natural and anthropized environments.

Status and Conservation. Least Concern (Cuttelod et al., 2011; Neubert et al., 2019).

STUDY AREA. Few shells were sampled scattered on the island, including the surroundings of the tower and in the litter of Pistacia lentiscus, always without the periostracum.

Cernuella (Cernuella) cfr. virgata (Da Costa, 1778)

Distribution AND Biology. EuropeanMediterranean distribution (Manganelli \& Giusti, 1987; Manganelli et al., 1995).

Thermophilic and xeroresistant, it is widespread in Sicily, at low and medium altitudes, in different natural environments, even degraded and anthropized, often in in numerous colonies on grasses and shrubs.

Status AND CONSERVATION. Least Concern (Cuttelod et al., 2011; Neubert et al., 2019).

STUDY AREA. In the Reserve, this species is quite common in grassland. It differs from the previous species for a bigger and more rounded shell and a less wide umbilicus (Figs. 28, 48).

Trochoidea (Trochoidea) caroni (Deshayes, 1832)

Distribution AND Biology. WesternMediterranean (Maio et al., 2013).

Relatively widespread in Sicily, from coastal areas to medium altitudes, especially in grassy habitats.

Status and CONSERVATION. Least Concern (Cuttelod et al., 2011; Neubert et al., 2019).
StUdy AREA. Uncommon in the reserve. Some shells have been found in different points of the island, both near the Torre di Fuori, along the coast and in the Pistacia lentiscus litter (Fig. 49).

REMARKS. Trochoidea (Trochoidea) caroni (Deshayes, 1832), with T. (T.) elegans (Gmelin, 1791) and T. (T.) trochlea (Pfeiffer, 1846), belong to a group of species which need a modern systematic review. In Sicily, Trochoidea (T.) caroni shows populations which differ in shape and size of the shell. The population we found in the Isola delle Femmine is morphologically similar to the typical material from Palermo (see Maio et al., 2013).

Familia CANARIELLIDAE Schileyko, 1991

Schileykiella reinae (Pfeiffer, 1856)

Distribution AND Biology. Endemic species of western Sicily with fragmented distribution.

Schileykiella reinae is a chalcophilous and hygrophilous species present in forest environments, Mediterranean scrub, at the base of limestone cliffs, or under rocks and debris.

StUdy AREA. A fair number of shells of this species were collected exclusively in the Pistacia lentiscus litter near outcropping rocks (Fig. 50).

Status and CONSERVATion. Near Threatened (Cuttelod et al., 2011; Neubert et al., 2019).

Remarks. The genus Schileykiella Manganelli, Sparacio et Giusti, 1989 includes three other species: S. parlatoris (Bivona, 1839), widespread in Sicily and Malta, S. bodoni Cianfanelli, Manganelli et Giusti, 2004, known only for Marettimo island (Cianfanelli et al., 2004) and $S$. mariarosariae R. Viviano, A. Viviano, Liberto, Reitano \& Sparacio, 2019 known only from Mount Pecoraro, Cinisi near Palermo (Viviano R. et al., 2019).

Familia HELICIDAE Rafinesque, 1815

Murella platychela platychela (Menke, 1830)

Distribution AND Biology. Endemic species of 
the North-Western Sicily, with several subspecies; the nominal subspecies was described from Monte Cuccio (Pfeiffer, 1931), a few kilometers South of the area covered by this study.

It is strictly calciphilous species and inhabits rocky sites.

Status and COnSERvation. Data Deficient following Neubert et al. (2019).

STUDY AREA. Murella platychela platychela was found on the rocky walls of the Reserve, particularly in the northern slope (Fig. 51).

Theba pisana (O.F. Müller, 1774)

Distribution AND BiOlogy. Mediterranean distribution extended to Macaronesia and to the North African and European Atlantic coasts (Gittenberger \& Ripken, 1987), passively diffused in other extra-European countries (Giusti et al., 1995). In Italy, it is present for almost all of peninsular Italy, Sicily and Sardinia (Alzona, 1971; Manganelli et al., 1995).

It is a thermophilic and photophilic species, typically linked to the dune system but also present in Sicily in more inland localities, at low altitudes, where it is found on various herbs and shrubs, often in large populations.

Status AND CONSERVATION. Least Concern (Cuttelod et al., 2011; Neubert et al., 2019).

STUDY AREA. Few live specimens and numerous fresh died shells have been found, both around the Torre di Fuori and along the coast (Figs. 29, 52).

\section{Eobania vermiculata (O.F. Müller, 1774)}

Distribution AND Biology. Mediterranean. Widespread by man in many non-Mediterranean countries.

It is thermophilic, common in many types of environments, both natural and anthropized, from a few meters above sea level up to medium altitudes.

StATUS AND CONSERVATION. Least Concern (Cuttelod et al., 2011; Neubert et al., 2019).

STUDY AREA. Living specimens of $E$. vermiculata have been found in the reserve under rocks or in limestone walls. In May, numerous young specimens were found adhering on the stems of Pennisetum setaceum and other plants (Figs. 30, $53,54)$.

REMARKS. Eobania vermiculata is present in all the circumsicilian islands with more or less differentiated populations (Benoit L., 1857-1862, 1875, 1882; Monterosato, 1892; Alzona, 1971)

\section{Cantareus apertus (Born, 1778)}

Distribution AND Biology. Species with Mediterranean distribution, present in almost all the Italian peninsula, Sicily and Sardinia.

It is thermophilic, common in open, arid, even anthropized and degraded environments, at low and medium altitudes. In Summer it estivates, under the ground, closing the aperture of the shell with a robust white and convex epiphragm.

STUDY AREA. Cantareus apertus has been found in the prairie and in the scrub with Pistacia lentiscus and Pennisetum setaceum, in the area along the coast (Fig. 55).

Status and CONSERvation. Least Concern (Cuttelod et al., 2011; Neubert et al., 2019).

Remarks. The genus Cantareus Risso, 1826 has included only this species for many years. Following Bouaziz-Yahiatene et al. (2019), mainly based on molecular data, C. subapertus (Ancey, 1893 ) and C. koraegaelius (Bourguignat in Locard, 1882) from Algeria are also attributed to this genus.

Cantareus apertus with Eobania vermiculata and Theba pisana are the best known edible molluscs in the Sicilian tradition (De Stefani, 1923; Pusateri, 2016; Sparacio, 2020). Local witnesses tell how, in the past, the islet was used for the collection of these shells for food purposes. The invasion of the brown rat (Rattus norvegicus) before and the presence of the yellow-legged gull (Larus michahellis) now strongly affected the populations of C. apertus and T. pisana.

\section{Erctella mazzullii (De Cristofori \& Jan, 1832)}

Distribution And Biology. Endemic species of the Palermo Mountains, widespread from Monte Pellegrino (Palermo) in the east to Monte Palmeto (Terrasini) in the west (Colomba et al., 2011; 2015).

The species of the genus Erctella Monterosato, 1894 are calciphilous and saxicavous (see Colomba 
et al., 2011 and cited bibliography; Hausdorf et al., 2020).

StATUS AND CONSERVATION. Endangered (Cuttelod et al., 2011; Neubert et al., 2019).

STUDY AREA. The species is quite rare and localized within the reserve, on the limestone walls. The only fresh died shell (Fig. 56) would seem to belong to the island population, while other very damaged shells would have been found near seagull nests, most likely preyed in the neighboring territories. The peculiar groupings of tunnels where E. mazzullii lives are present in various rocks of the Isola delle Femmine but its presence in the Reserve has to be confirmed (Fig. 57).

REMARKS. In Sicily, the genus Erctella includes two other species E. cephalaeditana (GiannuzziSavelli, Oliva et Sparacio, 1986), endemic of the Rocca of Cefalù, and E. insolida (Monterosato, 1892), widespread in the mountains of Trapani. A new species endemic to the island of Crete has recently been described: E. cretense Hausdorf, Bamberger et Walther, 2020 (Hausdorf et al., 2020).

\section{CONSIDERATIONS AND CONCLUSIONS}

This study has allowed us to reach a good state of knowledge on the malacological biodiverity of the Isola delle Femmine, but further investigations are recommended. This biotope was little known until now in the malacological literature and reported only by Sacchi (1954) for the presence of Tudorella panormitana.

A total of 23 species of terrestrial molluscs have been recorded in this study. They are concentrated in three characteristic environments of this small island: under stones and debris in the open areas and among the ruins around the Torre di Fuori, in the litter of Pistacia lentiscus and in the limestone walls. The most widespread and abundant species are Truncatellina callicratis (in Pistacia lentiscus litter), Ferrussacia folliculum and Caracollina lenticula (which are often found together, under stones), Eobania vermiculata (almost everywhere).

Judging by the presence of the empty shells, Cecilioides raphidia sicula and Vitrea cfr. Subrimata are also quite common.
Less numerous but fairly stable populations are those of Tudorella panormitana, Mastus pupa, Rumina decollata, Deroceras panormitanum, Xerotricha conspurcata, X. apicina, Cernuella cfr. virgata, Theba pisana and Cantareus apertus. The only exclusive endemism of the island appears to be very localized: Siciliaria leucophrina microinsularis n. ssp. Numerous fresh died shells of Murella platychela have been found on the limestone walls of the northern slope, while the presence of a living population of Erctella mazzullii needs confirmation.

Another 4 species have not been included to date, among the land molluscs living on Isola delle Femmine because they were found only with single empty shells of probable passive introduction: Cecilioides sp., Hohenwartiana aradasiana (Benoit, 1862), Murella globularis (Philippi, 1836) and M. muralis (O.F. Müller, 1774).

Mediterranean is the predominant chorotype (11 species equal to $48 \%$ ), extended to Macaronesia and Ocean Atlantic coasts (1 species) or limited to the western area (1 species). The EuropeanMediterranean chorotype has 6 species (26\%) of which 2 species extended to the Turanic area. Sicilian endemic species are in all $5(22 \%)$ and only one taxon is endemic to this islet (4\%).

In Table 1 the check list of land molluscs from Isola delle Femmine is compared with that from Grotta Conza Reserve, Sferracavallo (Reitano et al., 2012) and that of the coastal area of the municipality of Isola delle Femmine (personal data). In the Grotta Conza Reserve are recorded 41 species of land molluscs, thanks to the presence of a relatively intact and diversified environment. The coastal area in the municipality of Isola delle Femmine, although characterized by a heavy anthropic impact with some natural environments that have now disappeared, record 34 species strongly fragmented in the territory and isolated in relict environments.

The 23 species found on the Isola delle Femmine are also present in the neighbors localities mentioned, as can be seen from the direct comparison in table 1 . The total number of species registered in the Isola delle Femmine is lower than these locality but, in relation to the condition of insularity, the reduced territorial extension and the environmental difficulties constitute an important and peculiar insular malacocenosis. 
Almost all of these species, according to the IUCN (2017) criteria applied by Cuttelod et al. (2011) and Neubert et al. (2019), are Least Concern. Schileykiella reinae is Near Threatened species, Murella platychela platychela is Data Deficient, and Erctella mazzullii are classified as Endangered.

Siciliaria leucophryna microinsularis n. ssp. was listed by us as Critically Endangered.

Our actual knowledge on the history of animal populations of Isola delle Femmine does not enable to understand the real effects on the fauna and flora of this island of the anthropic impact. Indeed, the alteration of the original vegetation, the introduction of alien species such as brown rat or natural environmental effect of local seagull colony, presumably has led to the extinction of some taxa and to the rarefaction of others.

Present and future work on the distribution and abundance of animal populations such may be used to observe trends and assess threats to conservation, especially in the cases of endemic or rare species (Lo Cascio \& Pasta, 2012).

All the species of land molluscs present on the Isola delle Femmine, in relation to the delicate balance reached by these populations today, should be regularly monitored and subjected to a special surveillance and protection program. Finally, it is also necessary to investigate the identity of some invertebrates to understand better the biogeographical importance and biological heritage of this small island.

\begin{tabular}{|c|c|c|c|}
\hline Species & \begin{tabular}{|c|} 
Grotta Conza \\
Reserve (Reitano \\
et al., 2012)
\end{tabular} & $\begin{array}{c}\text { Isola delle Fem- } \\
\text { mine coastal area } \\
\text { (personal data) }\end{array}$ & $\begin{array}{l}\text { Isola delle Fem- } \\
\text { mine Reserve } \\
\text { (present paper) }\end{array}$ \\
\hline $\begin{array}{l}\text { Cochlostoma paladilhianum paladilhianum } \\
\text { (Saint-Simon, 1869) }\end{array}$ & $\mathbf{X}$ & $\mathbf{X}$ & \\
\hline Acicula benoiti (Bourguignat, 1864) & $\mathbf{X}$ & & \\
\hline Platyla subdiaphana (Bivona, 1839) & & $\mathbf{X}$ & \\
\hline Pomatias elegans (O.F. Müller, 1774) & $\mathbf{X}$ & $\mathbf{X}$ & \\
\hline Tudorella panormitana (Sacchi, 1954) & $\mathbf{X}$ & $\mathbf{X}$ & $\mathbf{L}$ \\
\hline Truncatella subcylindrica (Linnaeus, 1767) & & $\mathbf{X}$ & \\
\hline Gomphroa cylindracea (Calcara, 1840) & $\mathbf{X}$ & & \\
\hline Pleurodiscus balmei balmei (Potiez et Michaud, 1838) & $\mathbf{X}$ & $\mathbf{X}$ & \\
\hline Granopupa granum (Draparnaud, 1801) & $\mathbf{X}$ & $\mathbf{X}$ & $\mathbf{S}$ \\
\hline Rupestrella homala homala (Westerlund, 1892) & $\mathbf{X}$ & & \\
\hline Rupestrella rupestris margritae Beckmann, 2002 & $\mathbf{X}$ & $\mathbf{X}$ & \\
\hline Truncatellina callicratis (Scacchi, 1833) & $\mathbf{X}$ & $\mathbf{X}$ & $\mathbf{L}$ \\
\hline Mastus pupa (Linnaeus, 1758) & $\mathbf{X}$ & & $\mathbf{L}$ \\
\hline Cecilioides raphidia sicula Beckmann et Falkner, 2008 & $\mathbf{X}$ & $\mathbf{X}$ & $\mathbf{S}$ \\
\hline Cecilioides sp. & & $\mathbf{X}$ & \\
\hline Hohenwartiana aradasiana (Benoit, 1862) & $\mathbf{X}$ & $\mathbf{X}$ & \\
\hline Ferussacia folliculum (Schröter, 1784) & $\mathbf{X}$ & $\mathbf{X}$ & $\mathbf{L}$ \\
\hline Rumina decollata (Linnaeus, 1758) & $\mathbf{X}$ & $\mathbf{X}$ & $\mathbf{L}$ \\
\hline
\end{tabular}




\begin{tabular}{|c|c|c|c|}
\hline Siciliaria leucophryna leucophryna (L. Pfeiffer, 1862) & $\mathbf{X}$ & & \\
\hline Siciliaria leucophryna microinsularis $\mathrm{n} . \mathrm{spp}$. & & & $\mathbf{L}$ \\
\hline Papillifera papillaris affinis (Philippi, 1836) & $\mathbf{X}$ & & \\
\hline Poiretia dilatata dilatata (Philippi, 1836) & $\mathbf{X}$ & & \\
\hline Vitrea subrimata (Reinhardt, 1871) & $\mathbf{X}$ & $\mathbf{X}$ & $\mathbf{L}$ \\
\hline Oxychilus fuscosus (Rossmässler, 1838) & $\mathbf{X}$ & $\mathbf{X}$ & \\
\hline Daudebardia brevipes sicula (Bivona, 1839) & $\mathbf{X}$ & & \\
\hline Milax nigricans (Philippi, 1836) & $\mathbf{X}$ & & \\
\hline Tandonia sowerbyi (A. Férussac, 1823) & $\mathbf{X}$ & & \\
\hline Limacus flavus (Linnaeus, 1758) & & $\mathbf{X}$ & \\
\hline Ambigolimax valentianus (A. Férussac, 1821) & & $\mathbf{X}$ & \\
\hline Deroceras panormitanum (Lessona et Pollonera, 1882) & $\mathbf{X}$ & & $\mathbf{L}$ \\
\hline Caracollina lenticula (Michaud, 1831) & $\mathbf{X}$ & $\mathbf{X}$ & $\mathbf{L}$ \\
\hline Monacha consona (Rossmässler, 1839) & $\mathbf{X}$ & & \\
\hline Monacha gregaria (Rossmässler, 1839) & $\mathbf{X}$ & & \\
\hline Cochlicella acuta (O.F. Müller, 1774) & $\mathbf{X}$ & $\mathbf{X}$ & $\mathbf{L}$ \\
\hline Cochlicella conoidea (O.F. Müller, 1774) & & $\mathbf{X}$ & \\
\hline Cernuella cfr. cisalpina (Rossmässler, 1837) & $\mathbf{X}$ & $\mathbf{X}$ & $\mathbf{S}$ \\
\hline Cernuella cfr. virgata (Da Costa, 1778) & $\mathbf{X}$ & $\mathbf{X}$ & $\mathbf{L}$ \\
\hline Xerotricha apicina (Lamarck, 1822) & & $\mathbf{X}$ & $\mathbf{L}$ \\
\hline Xerotricha conspurcata (Draparnaud, 1801) & $\mathbf{X}$ & & $\mathbf{L}$ \\
\hline Schileykiella reinae (Pfeiffer, 1856) & $\mathbf{X}$ & $\mathbf{X}$ & $\mathbf{S}$ \\
\hline Polygyra cereolus (Megerle von Mühlfeldt, 1818) & & $\mathbf{X}$ & \\
\hline Discus rotundatus rotundatus (O.F. Müller, 1774) & $\mathbf{X}$ & & \\
\hline Trochoidea caroni (Deshayes, 1832) & $\mathbf{X}$ & & $\mathbf{S}$ \\
\hline Trochoidea pyramidata (Draparnaud, 1805) & $\mathbf{X}$ & & \\
\hline Campylaea macrostoma (Rossmässler, 1837) & $\mathbf{X}$ & & \\
\hline Murella platychela platychela (Menke, 1830) & $\mathbf{X}$ & $\mathbf{X}$ & $\mathbf{S}$ \\
\hline Theba pisana (O.F. Müller, 1774) & & $\mathbf{X}$ & $\mathbf{L}$ \\
\hline Eobania vermiculata (O.F. Müller, 1774) & $\mathbf{X}$ & $\mathbf{X}$ & $\mathbf{L}$ \\
\hline Cantareus apertus (Born, 1778) & $\mathbf{X}$ & $\mathbf{X}$ & $\mathbf{S}$ \\
\hline Cornu aspersum (O.F. Müller, 1774) & $\mathbf{X}$ & $\mathbf{X}$ & \\
\hline Erctella mazzullii (De Cristofori et Jan, 1832) & $\mathbf{X}$ & $\mathbf{X}(\mathbf{E X})$ & $\mathbf{S}$ \\
\hline
\end{tabular}

Table 1. Comparison between the land molluscs populations found in the Grotta Conza Natural Reserve, Sferracavallo (Reitano et al., 2012), in the coastal area of Isola delle Femmine Municipality (personal data), and in the Isola delle Femmine Nature Reserve (present paper). $\mathrm{X}=$ presence; $\mathrm{L}=$ living specimen; $\mathrm{S}=$ shell; $\mathrm{EX}=$ extinct species. 

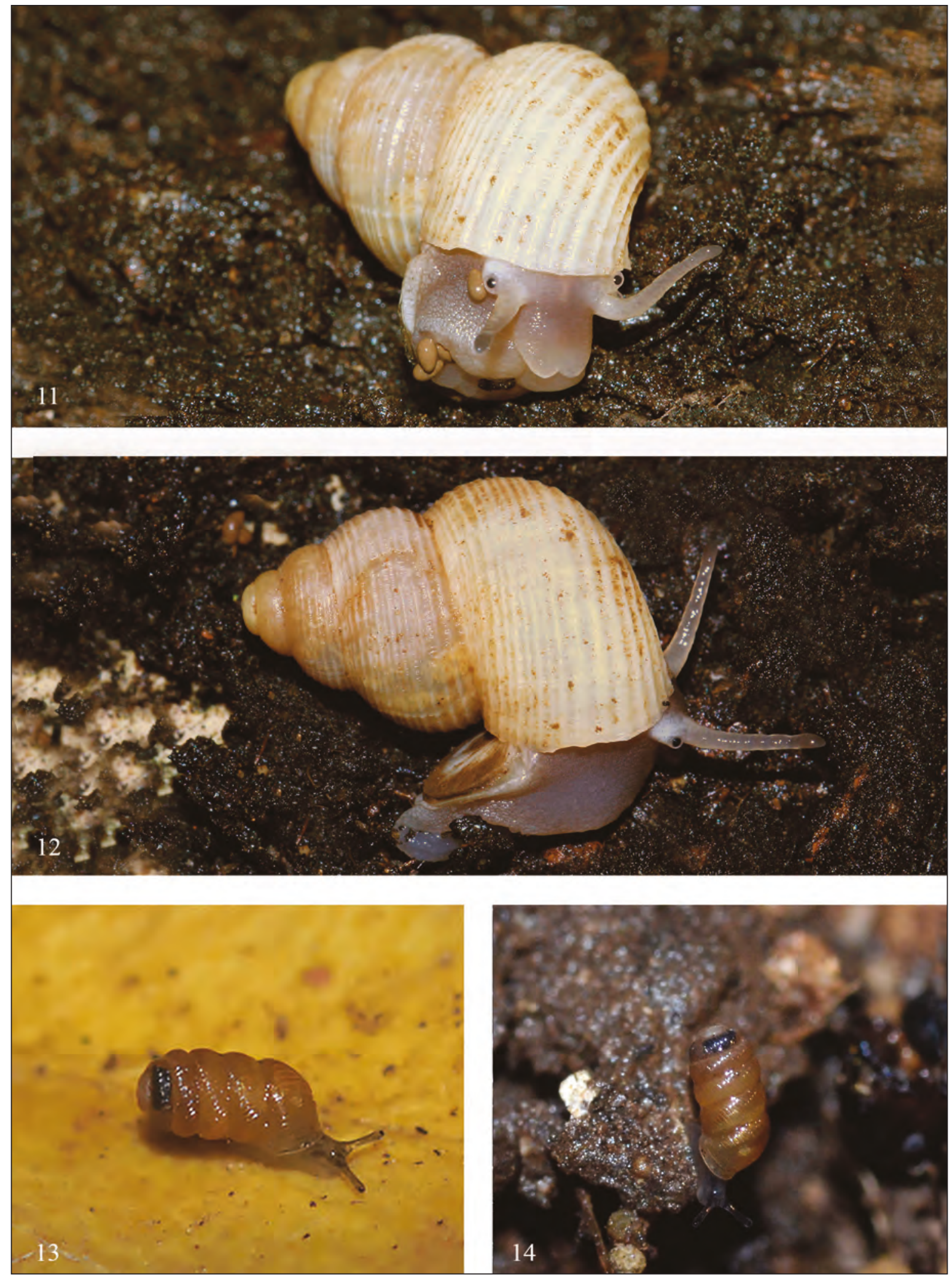

Figures 11-14. Living land snails from Isola delle Femmine.

Figs. 11, 12: Tudorella panormitana. Figs. 13, 14: Truncatellina callicratis. 

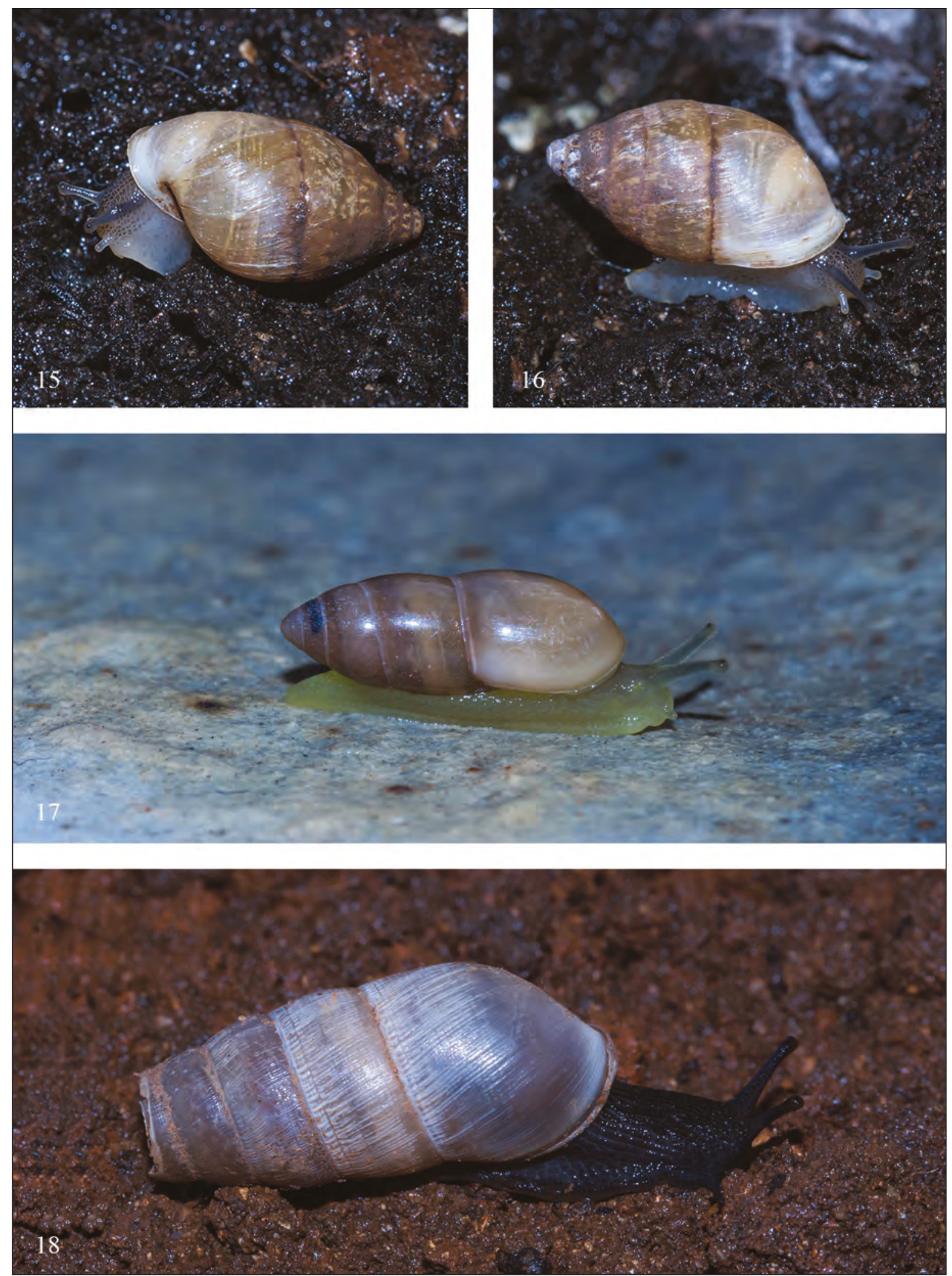

Figures 15-18. Living land snails from Isola delle Femmine. Figs. 15, 16: Mastus pupa. Fig. 17: Ferussacia folliculum. Fig. 18: Rumina decollata. 

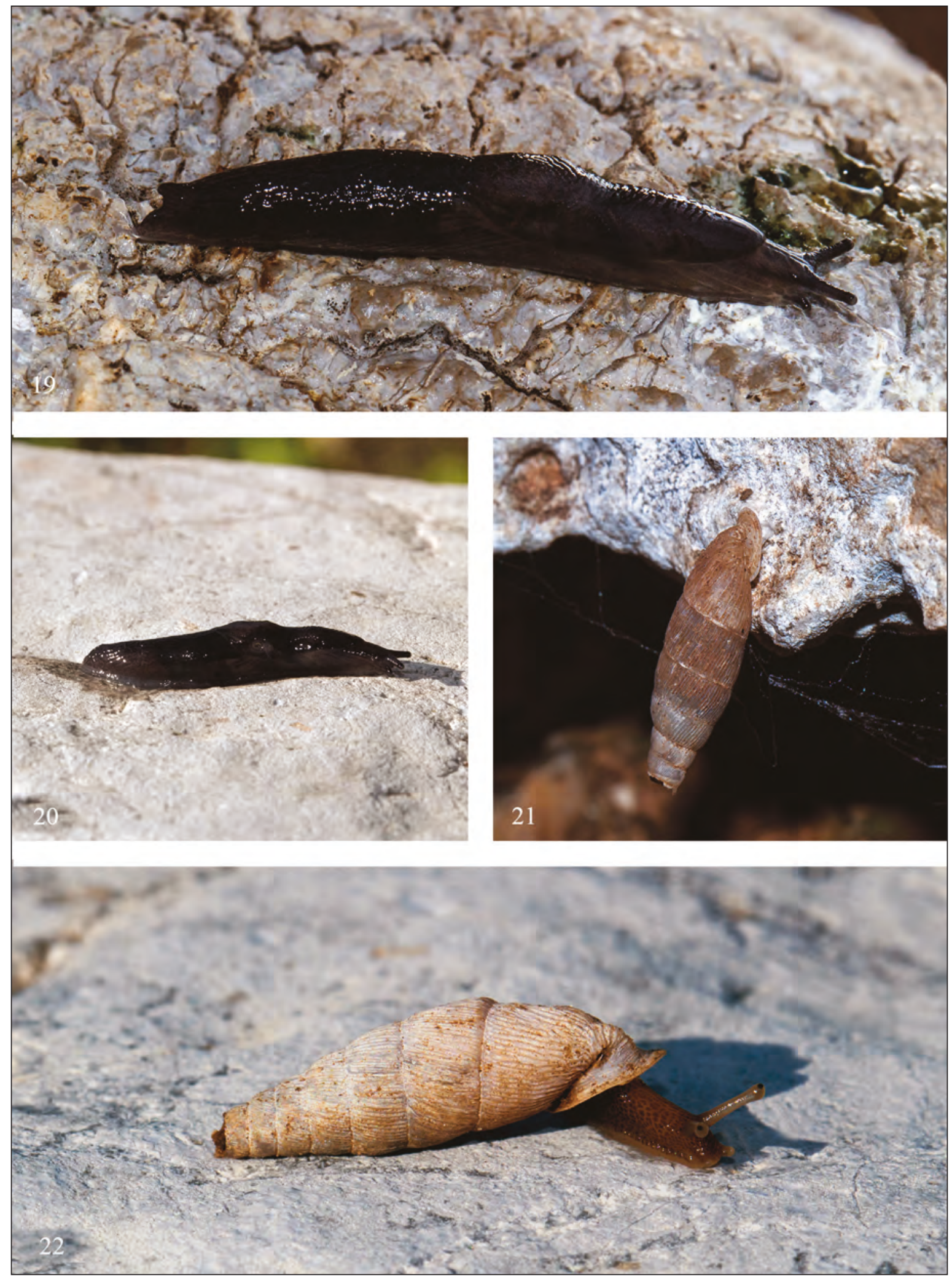

Figures 19-22. Living land snails from Isola delle Femmine. Figs. 19, 20: Deroceras panormitanum. Figs. 21, 22: Siciliaria leucophryna microinsularis n. ssp. 

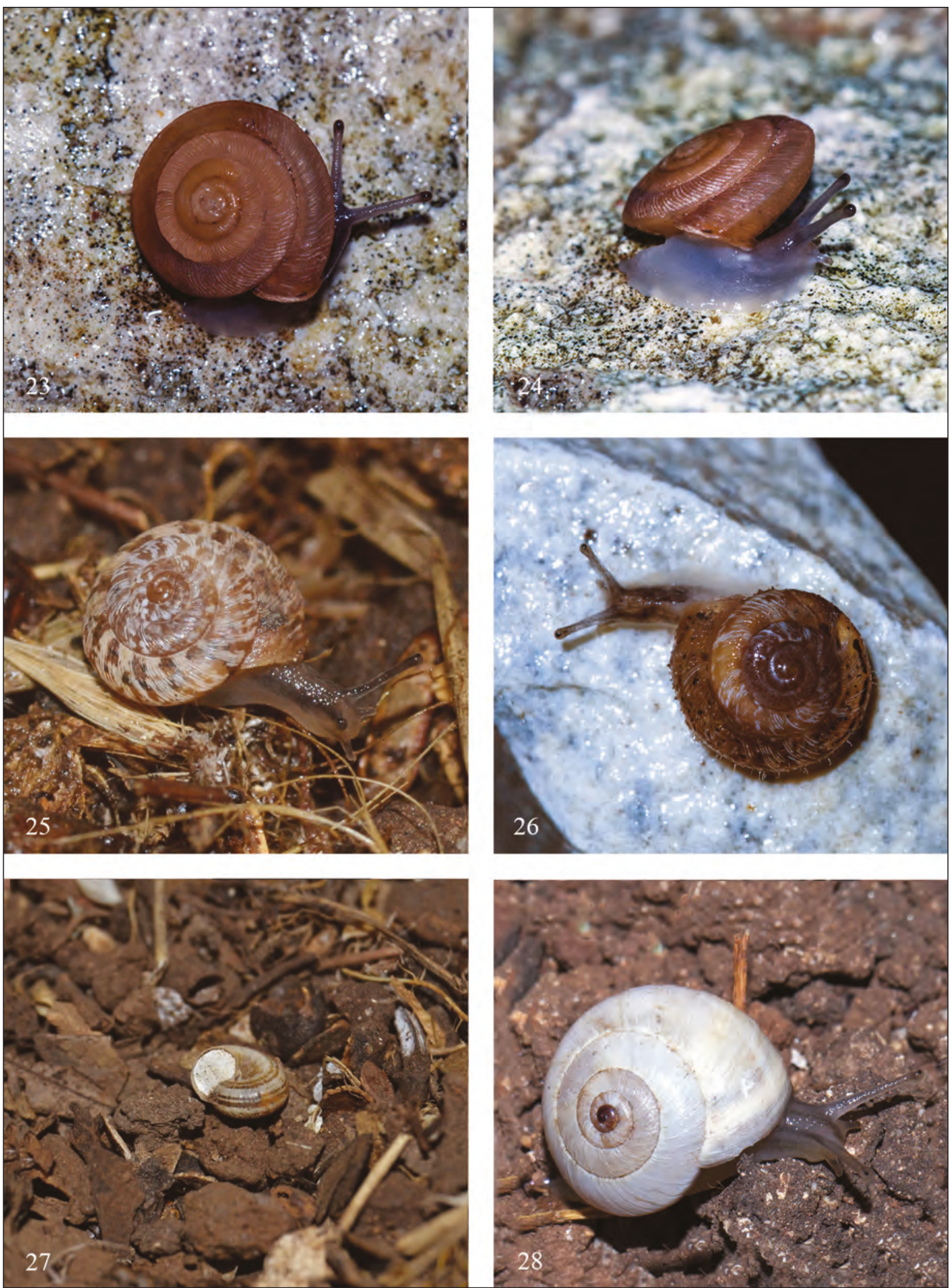

Figures 23-28. Living land snails from Isola delle Femmine. Figs. 23, 24: Caracollina lenticula. Figs. 25, 26: Xerotricha conspurcata. Fig. 27: Xerotricha apicina. Fig. 28: Cernuella cfr. virgata. 

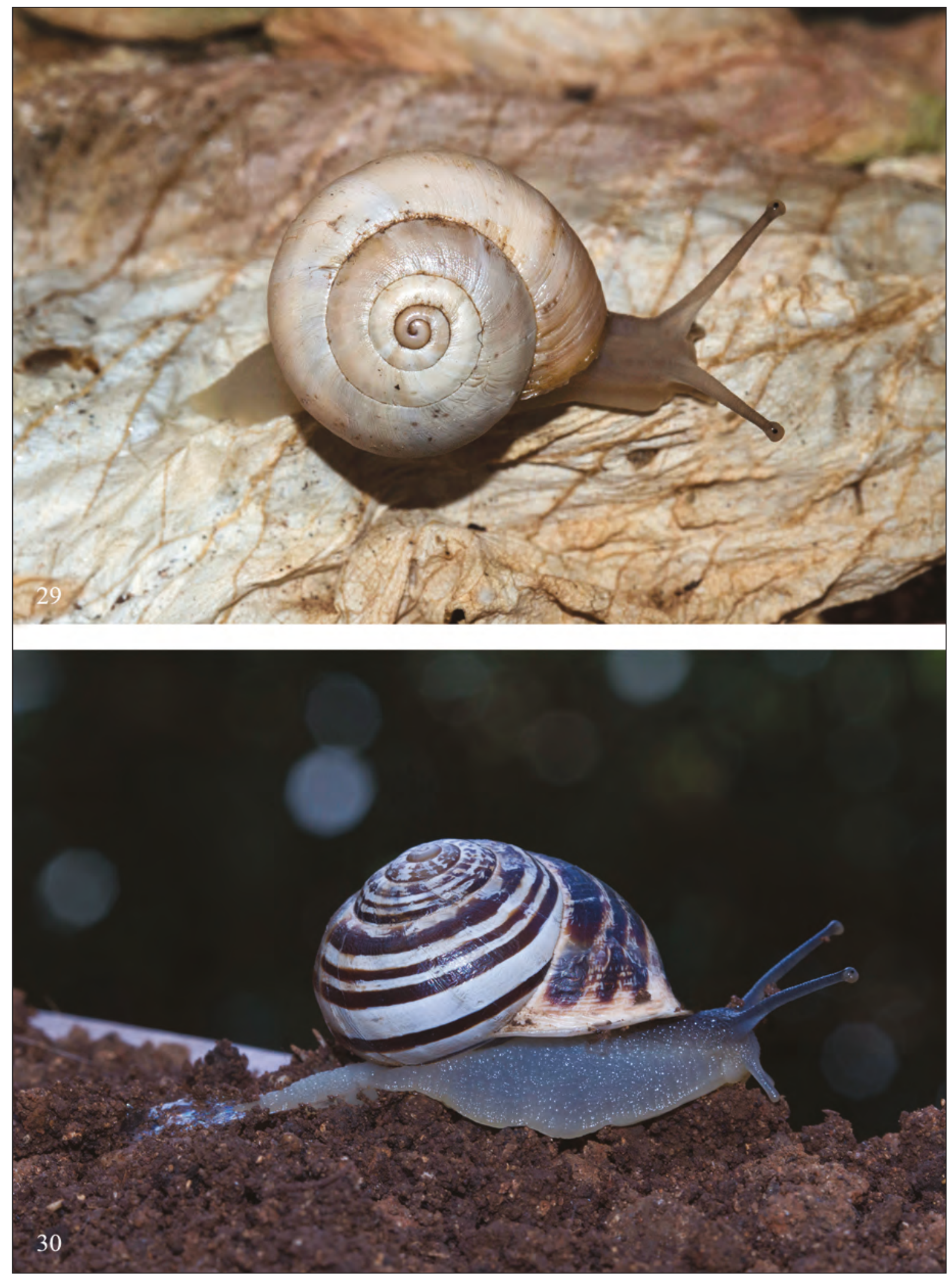

Figures 29, 30. Living land snails from Isola delle Femmine. Fig. 29: Theba pisana. Fig. 30: Eobania vermiculata. 


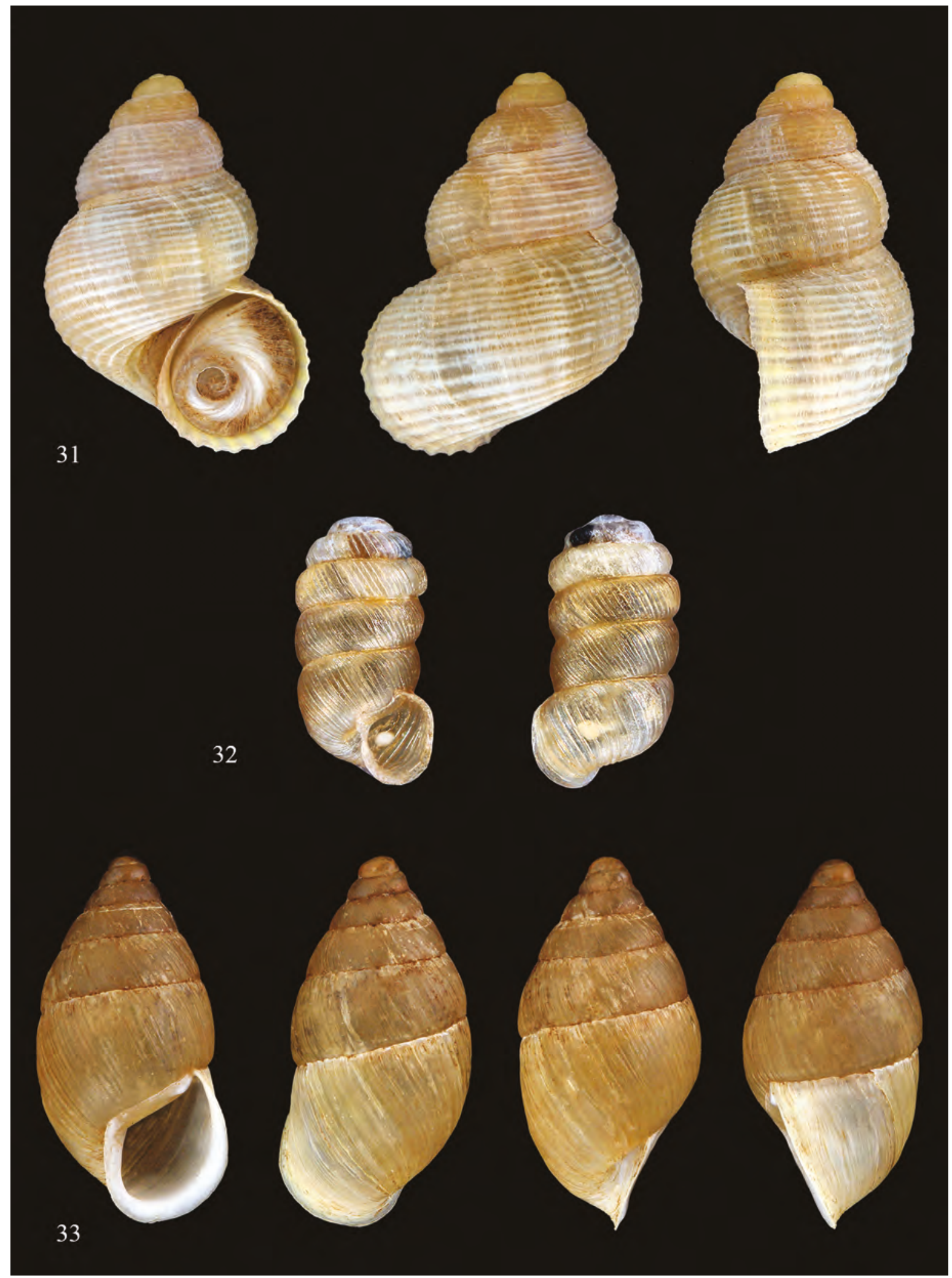

Figures 31-33. Land snails from Isola delle Femmine. Fig. 31: Tudorella panormitana, $\mathrm{H}=16.2 \mathrm{~mm}$. Fig. 32: Truncatellina callicratis, $\mathrm{H}=2 \mathrm{~mm}$. Fig. 33: Mastus pupa, $\mathrm{H}=13.2$. $\mathrm{mm}$. 


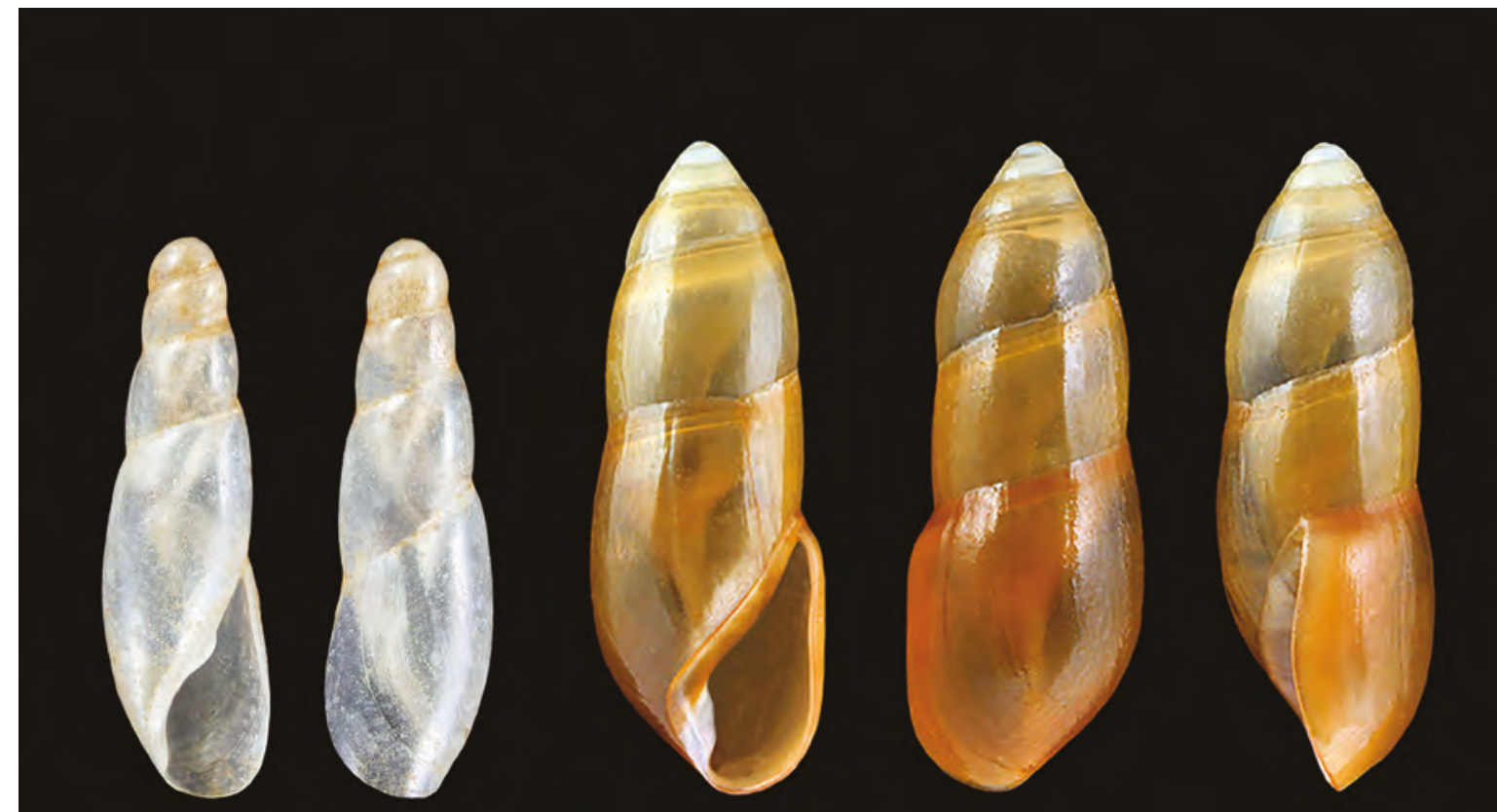

34

35
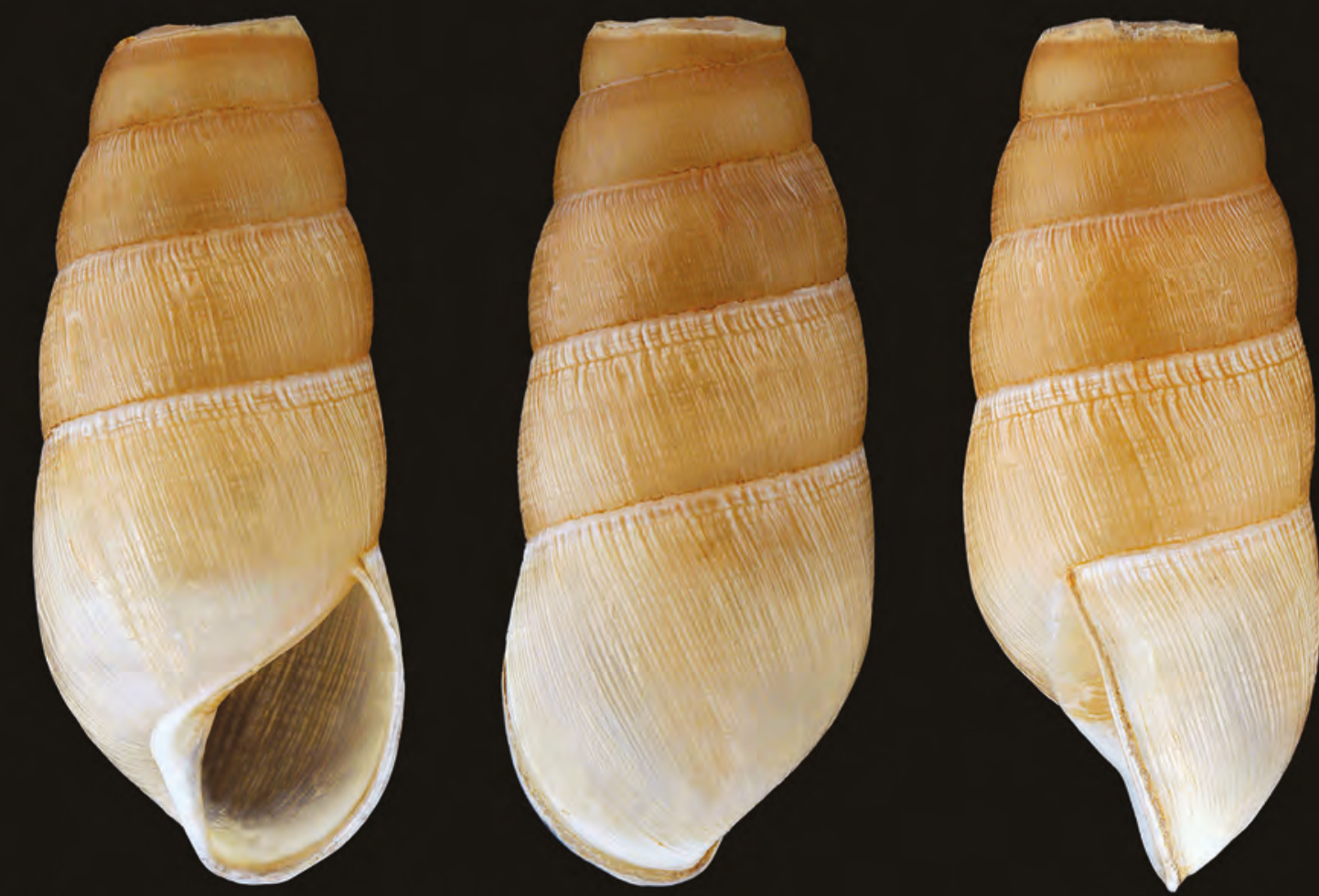

36

Figures 34-36. Land snails from Isola delle Femmine. Fig. 34: Cecilioides (Cecilioides) raphidia sicula, $\mathrm{H}=5.1 \mathrm{~mm}$. Fig. 35: Ferussacia folliculum, $\mathrm{H}=10.4 \mathrm{~mm}$. Fig. 36 : Rumina decollata, $\mathrm{H}=26.8 \mathrm{~mm}$. 


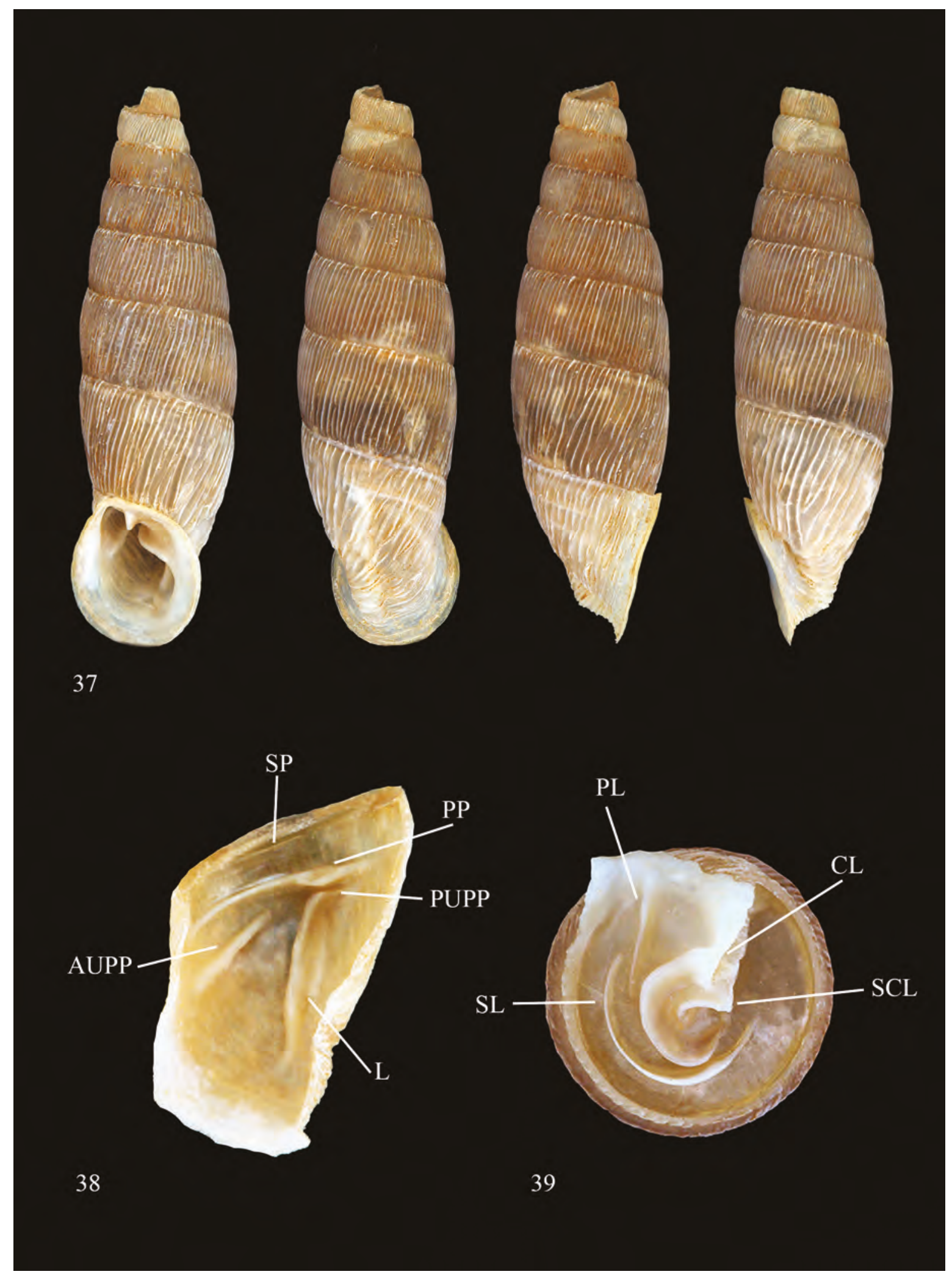

Figures 37-39. Land snails from Isola delle Femmine. Fig. 37: Siciliaria leucophryna microinsularis n. ssp. holotypus, $\mathrm{H}=17 \mathrm{~mm}$. Fig. 38: paratype, palatum. Fig. 39: paratype, parietum. 


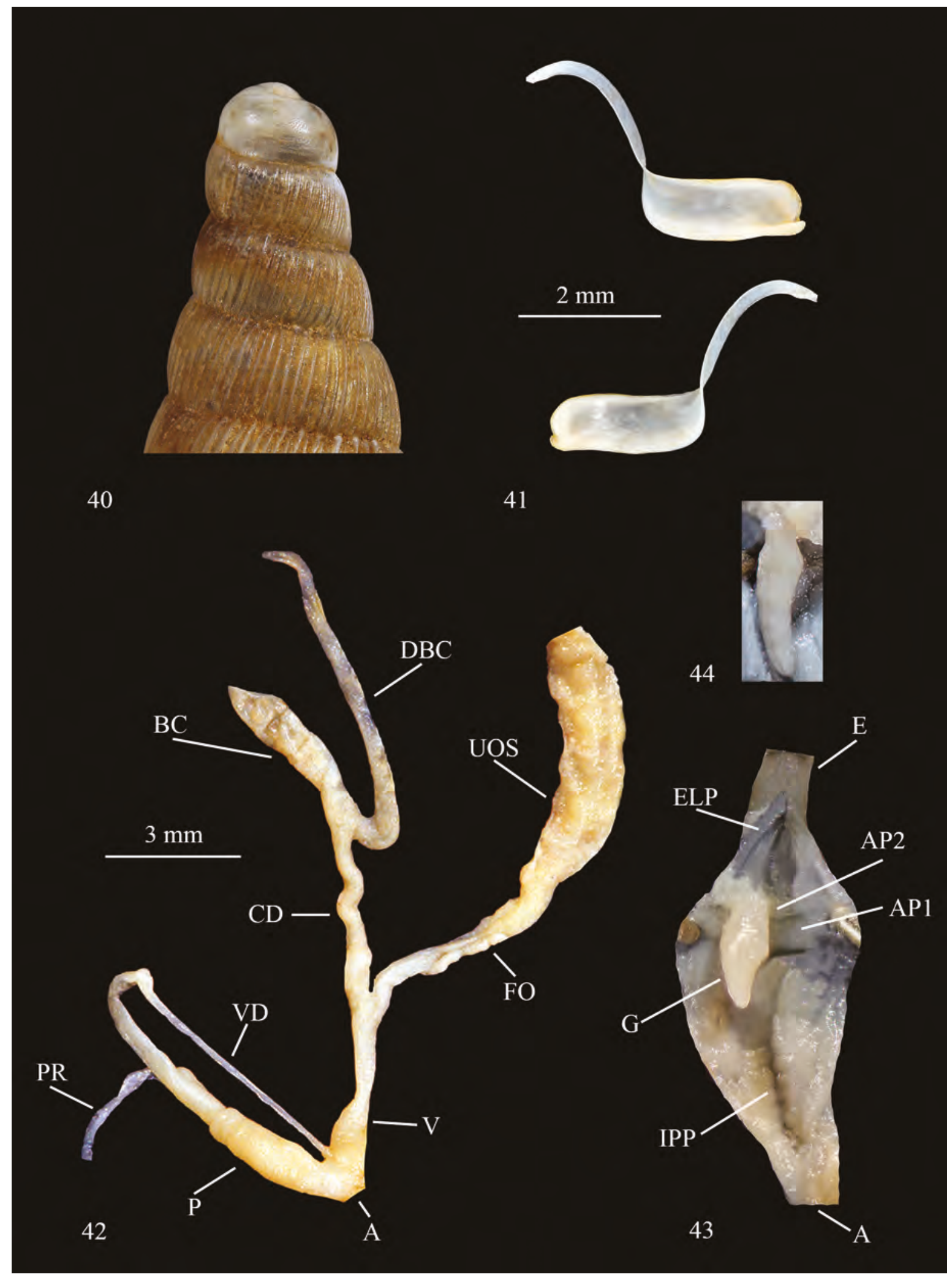

Figures 40-44. Land snails from Isola delle Femmine, Siciliaria leucophryna microinsularis n. ssp. paratype. Fig. 40: shell apex. Fig. 41: clausilium. Fig. 42: genitalia. Fig. 43: inner penis. Fig. 44: penial pseudopapilla. 


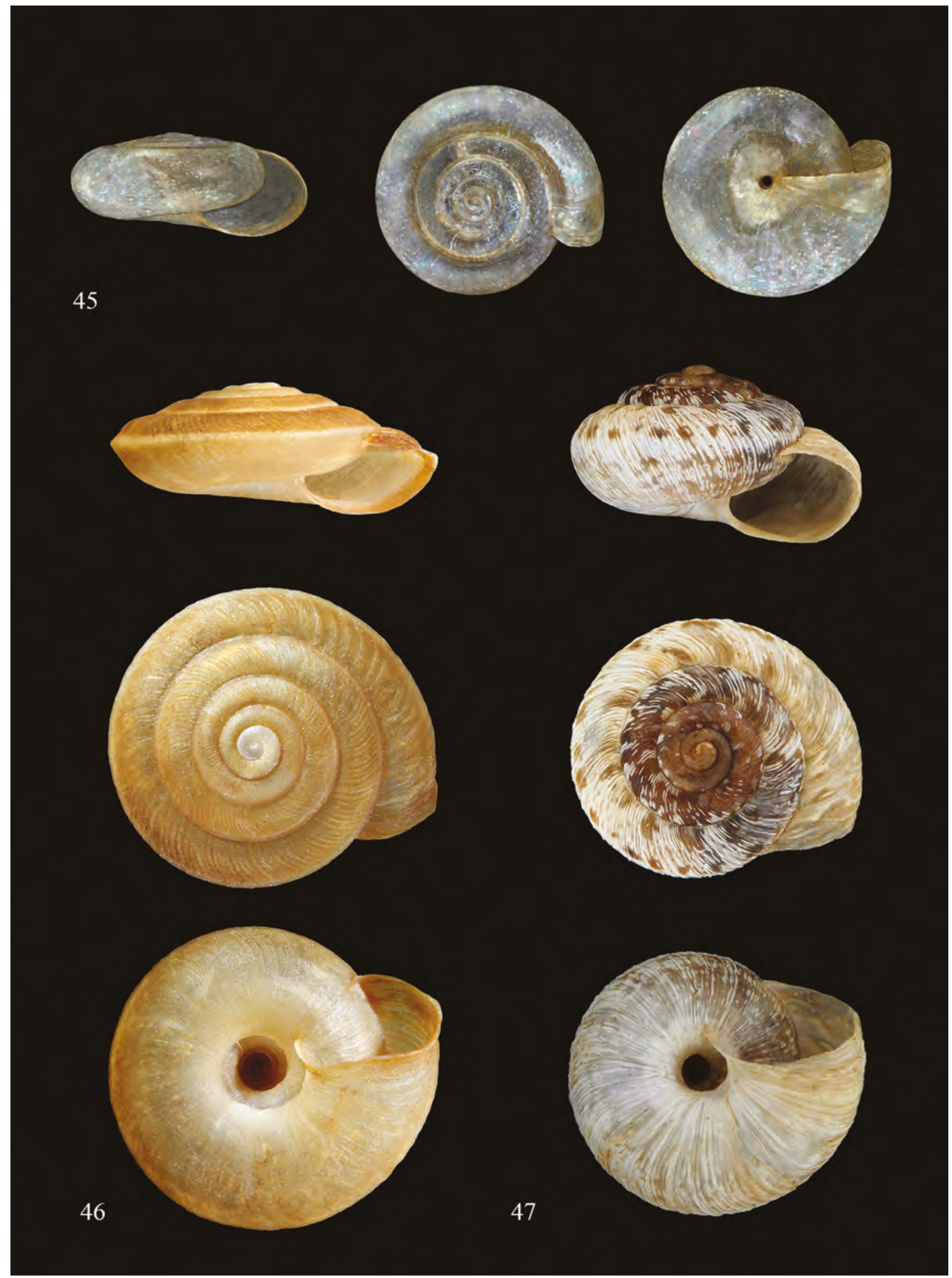

Figures 45-47. Land snails from Isola delle Femmine. Fig. 45: Vitrea subrimata, $\mathrm{H}=1.9 \mathrm{~mm}, \mathrm{D}=3.9 \mathrm{~mm}$. Fig. 46 : Caracollina lenticula, $\mathrm{H}=5.2 \mathrm{~mm}, \mathrm{D}=10 \mathrm{~mm}$. Fig. 47 : Xerotricha conspurcata $\mathrm{H}=4.2 \mathrm{~mm}, \mathrm{D}=6.8 \mathrm{~mm}$. 


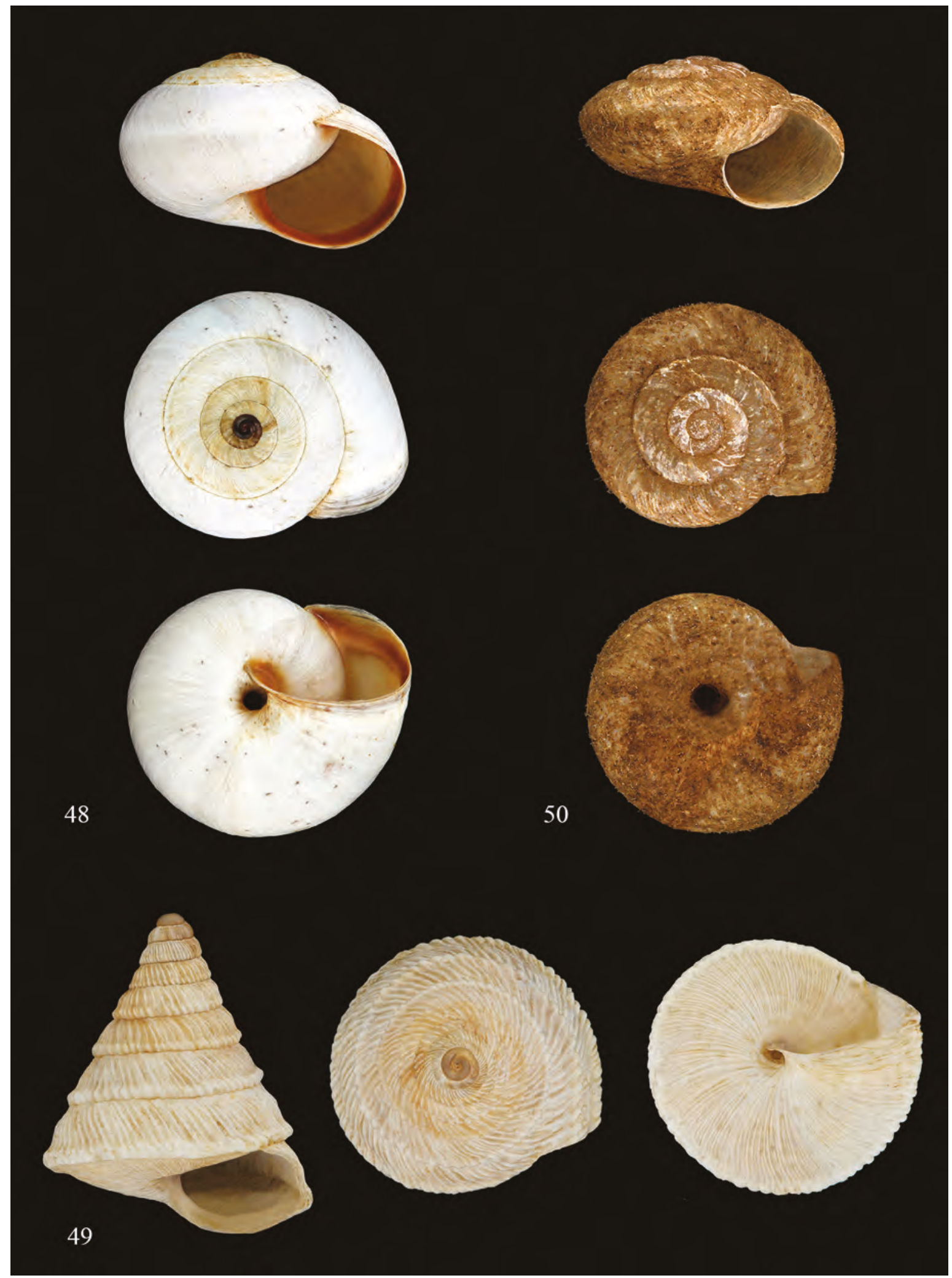

Figures 48-50. Land snails from Isola delle Femmine. Fig. 48: Cernuella (Cernuella) cfr. virgata $\mathrm{H}=11 \mathrm{~mm}, \mathrm{D}=14$ mm. Fig. 49: Trochoidea caroni $\mathrm{H}=10 \mathrm{~mm}, \mathrm{D}=8.2 \mathrm{~mm}$. Fig. 50 : Schileykiella reinae, $\mathrm{H}=4.3 \mathrm{~mm}$., $\mathrm{D}=7.3 \mathrm{~mm}$. 


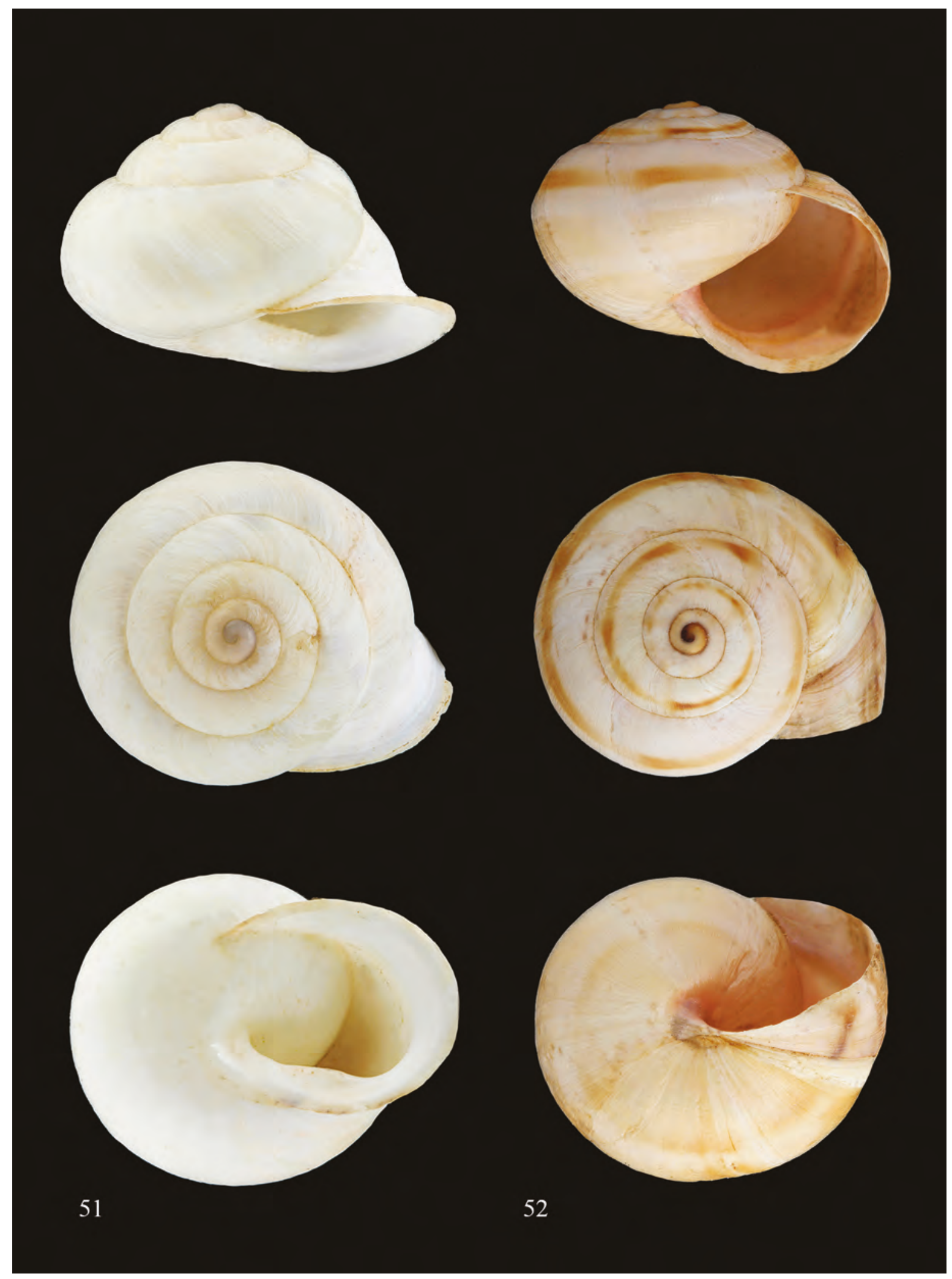

Figures 51, 52. Land snails from Isola delle Femmine. Fig. 51: Murella platychela platychela., $\mathrm{H}=15.5 \mathrm{~mm}$, $\mathrm{D}=21 \mathrm{~mm}$. Fig. 52: Theba pisana, $\mathrm{H}=12.5 \mathrm{~mm}, \mathrm{D}=17 \mathrm{~mm}$. 


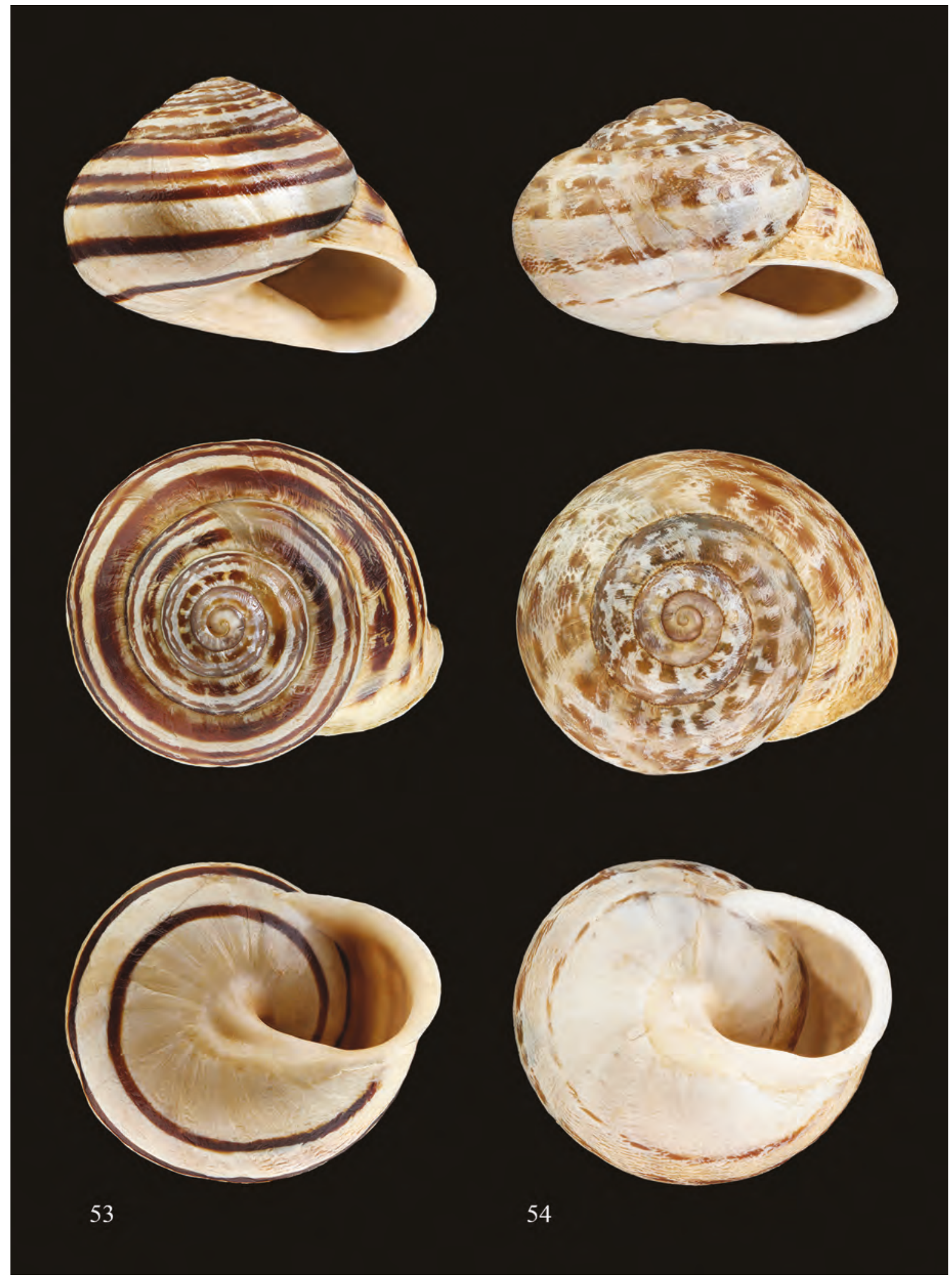

Figures 53, 54. Land snails from Isola delle Femmine: Eobania vermiculata with the two most common shell phenotypes. Fig. 53: $\mathrm{H}=21 \mathrm{~mm}, \mathrm{D}=24 \mathrm{~mm}$. Fig. $54: \mathrm{H}=17.5 \mathrm{~mm}, \mathrm{D}=25.5 \mathrm{~mm}$. 


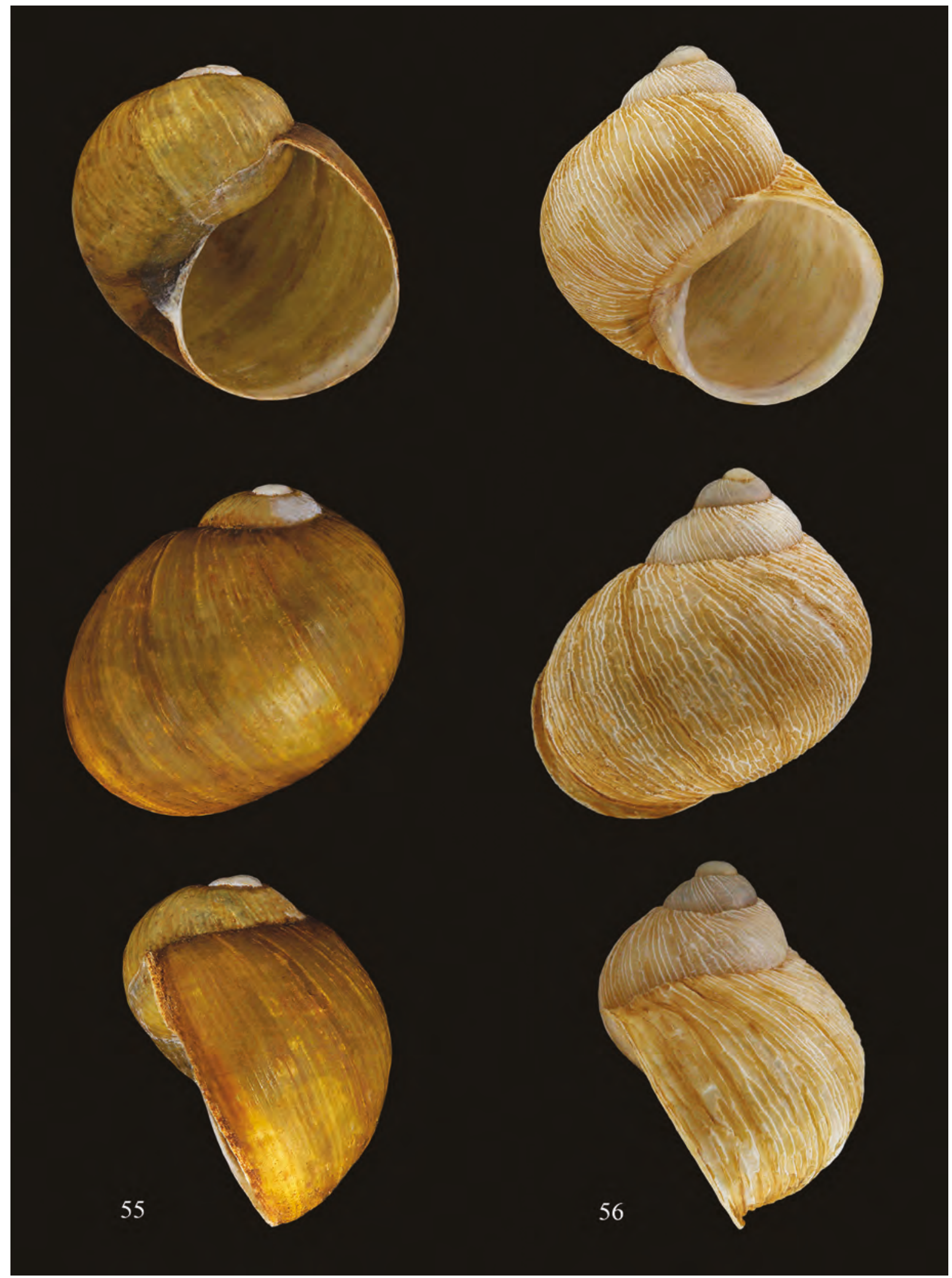

Figures 55, 56. Land snails from Isola delle Femmine. Fig. 55: Cantareus apertus, $\mathrm{H}=21.5 \mathrm{~mm}, \mathrm{D}=23 \mathrm{~mm}$. Fig. 56: Erctella mazzullii: $\mathrm{H}=17.5 \mathrm{~mm}, \mathrm{D}=25.5 \mathrm{~mm}$. 


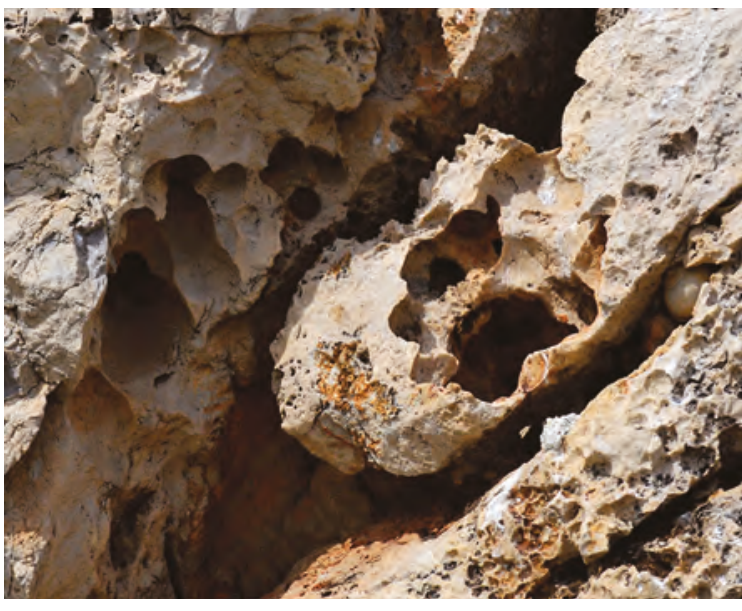

Figure 57. Isola delle Femmine: tunnels dug into limestone by Erctella specimens.

\section{ACKNOWLEDGEMENTS}

We want to thank very much Vincenzo Di Dio, the director of the Reserve "Isola delle Femmine" (palermo, Italy) who made it possible to collect the material for this study and facilitated all phases such as use of the boat to reach the island, sampling, etc. Furthermore, he has undertaken with the authors constructive debates on the status of knowledge of Reserve. Activity carried out within the convention between the SAAF department and Lipu ("Check list delle specie di invertebrati, vertebrati ed individuazione delle migliori tecniche di propagazione del Lentisco (Pistacia lentiscus) presenti nell'Isola delle Femmine, Palermo", project head Tommaso La Mantia, Professor at the University of Palermo). We also are indebted with Antonino Barbera (Castelvetrano, Italy) and Marcello Romano (Capaci, Italy) who authorized the use of their photographs.

\section{REFERENCES}

Abate B., Catalano R. \& Renda P., 1978. Schema geologico dei Monti di Palermo. Bollettino della Società geologica italiana, 97: 807-819.

Aliquò V., 1996. La collezione entomologica Alliata del Museo Regionale di Terrasini. Coleoptera: 1. Cicindelidae; 2. Tenebrionidae. Il Naturalista siciliano, 16: $13-28$.

Alzona C., 1971. Malacofauna Italica. Catalogo e bibliografia dei molluschi viventi, terrestri e d'acqua dolce. Atti della Società Italiana di Scienze naturali e del Museo Civico di Storia Naturale di Milano, 111: $1-433$.

Beckmann K.H., 1990. Beiträge zur Kenntnis der Landmolluskenfauna Siziliens mit der Beschreibung von Muticaria neuteboomi spec. nov. (Gastropoda Pulmonata: Clausiliidae). Basteria, 54: 75-85.

Beckmann K.H. \& Falkner G., 2008. Beiträge zur nomenklatur der europäischen Binenmollusken, XXI. Zur kenntnis der sizilianischen Blindschnecken Cecilioides raphidia (Bourguignat 1856) und Cecilioides actoniana (Benoit 1862) (Gastropoda: Ferussaciidae). Heldia, 5: 137-138, Taf. 19.

Benoit L., 1857-1862. Illustrazione sistematica critica iconografica de' testacei estramarini della Sicilia Ulteriore e delle isole circostanti. Gaetano Nobile, Napoli, 248 pp., 8 pls. [Quaderno 1.o: pp. i-xvi, 152, pls.1-2 (1857); Quaderno 2.o: pp. 53-116, pls. 3-4 (1857); Quaderno 3.o: pp. 117-180, pls. 5-6 (1859); Quaderno 4.o: pp. 181-248, pls. 7-8 (1862). The publication date of three additional plates, 9, 11 and 12, is unknown.].

Benoit L., 1875. Catalogo delle conchiglie terrestri e fluviatili della Sicilia e delle Isole circostanti. Bullettino della Società Malacologica Italiana, 1: 129-163.

Benoit L., 1882. Nuovo catalogo delle conchiglie terrestri e fluviatili della Sicilia o continuazione alla illustrazione sistematica critica iconografica de' testacei estramarini della Sicilia Ulteriore e delle isole circostanti. Tipografia D'Amico, Messina, 176 pp.

Boettger O., 1879. In: Rossmässler E.A., Iconographie der Land- und SūsswasserMolluscker, mit vorzūgliker Berūcksichtingung der europäischen noch nicht abgebildeten Arten. Neue Folge, Wiesbaden, (1) 6 (4/5): 52-153, tables 167-178.

Bonardi G., de Capoa P., Di Staso A., Estevez A., MartínMartín M., Martín-Rojas I., Perrone V. \& Tent-Manclús J.E., 2003. Oligocene to Early Miocene depositional and structural evolution of the Calabria-Peloritani Arc southern subterrane (Italy) and geodynamic correlations with the Spain Betics and Morocco Rif. Geodinamica Acta, 16: 149-169. Retrieved from http://www.tandfonline.com/loi/ tgda20\#.VbtWnSQ2Cbk https://doi.org/10.1016/j.geoact.2003.06.001

Bouaziz-Yahiatene H., Inäbnit T., Medjdoub-Bensaad F., Colomba M.S., Sparacio I., Gregorini A., Liberto F. \& Neubert E., 2019. Revisited - the species of Tweeting vine-yard snails, genus Cantareus Risso, 1826 (Stylommatophora, Helicidae, Helicinae, Otalini). ZooKeys, 876: 1-26. 
https://doi.org/10.3897/zookeys.876.36472http://zoo keys.pensoft.net

Caldarella O., La Rosa A., Pasta S. \& Di Dio V., 2010. La flora vascolare della Riserva Naturale Orientata, Isola delle Femmine (Sicilia nord-occidentale): Aggiornamento della check-list e commento del turnover. Il Naturalista siciliano, 34: 421-476.

Canale D.E., Di Dio V., Massa B. \& Mori E., 2019. First successful eradication of Norway rats Rattus norvegicus from a small Mediterranean island (Isola delle Femmine, Italy). Folia Zoologica, 68: 21-26. https://doi.org/10.25225/fozo.060.2019

Carapezza A., 2006. The genus Hadrophyes Puton in the central Mediterranean (Heteroptera Miridae Phylinae). Il Naturalista siciliano, 30: 243-347.

Catalano R., Abate B. \& Renda P., 1979. Carta geologica dei Monti di Palermo (scala 1:50.000) e note illustrative. Istituto di Geologia dell'Università di Palermo.

Catalano R., Basilone L., Di Maggio C., Gasparo Morticelli M., Agate M. \& Avellone G., 2013a. Note illustrative della Carta Geologica d'Italia alla scala 1:50.000, Foglio 594-585 Partinico-Mondello. ISPRA - Servizio Geologico D'Italia.

Catalano R., Valenti V., Accaino F., Sulli A., Tinivella U., Gasparo Morticelli M., Zanolla C. \& Giustiniani M., 2013b. Sicily's fold/thrust belt and slab rollback: The SI.RI.PRO seismic crustal transect. Journal of Geological Society London, 170: 451464.

Cianfanelli S., Manganelli G. \& Giusti F., 2004. A new species of Schileykiella from Marettimo (Aegadian islands, Italy) and discussion of relationships of cilielline Hygromiids (Gastropoda, Polmonata, Hygromiidae). Journal of Conchology, 38: 209230.

Colomba M.S., Gregorini A., Liberto F., Reitano A., Giglio S. \& Sparacio I., 2011. Monographic revision of the endemic Helix mazzullii De Cristofori \& Jan, 1832 complex from Sicily and reintroduction of the genus Erctella Monterosato, 1894 (Pulmonata, Stylommatophora, Helicidae). Zootaxa, 3134: 1-42.

Cossignani T. \& Cossignani V., 1995. Atlante delle conchiglie terrestri e dulciacquicole italiane. L'Informatore Piceno, Ancona, 208 pp.

Cossignani T. \& Cossignani V., 2020. Atlante delle conchiglie terrestri e dulciacquicole italiane (nuova edizione 2020). L'Informatore Piceno, Ancona, 228 pp.

Cowie R.H., 2001. Can snails ever be effective and safe biocontrol agents? International Journal of Pest Management, 47: 23-40.

Colomba M.S., Gregorini A., Liberto F., Reitano A., Giglio S. \& Sparacio I., 2015. The genus Erctella
Monterosato, 1894: new molecular evidence (Pulmonata Stylommatophora Helicidae). Biodiversity Journal, 6 : 401-411.

Cuttelod A., Seddon M. \& Neubert E., 2011. European Red List of Non-marine Molluscs. Luxembourg: Publications Office of the European Union.

De Mattia W., 2017. Charpentieria leucophryna. The IUCN Red List of Threatened Species. 5407 https://www.iucnredlist.org/species/171446/1326286

De Stefani T., 1923. Il commercio della chiocciola e notizie su alcune Helix di Sicilia. Allevamenti, 4: 29.

Di Dio V., 2011. La Riserva Naturale Orientata Isola delle Femmine, pp. 25-29. In: AA.VV. (a cura di), L'educazione Ambientale per la sostenibilità dello sviluppo. Gazzetta Ambiente, 17(4).

Di Martino A. \& Di Trapani S., 1964. Flora e vegetazione dell'Isola delle Femmine. Lavori dell'Istituto Botanico e Giardino Coloniale di Palermo, 20: 121159.

Doglioni C., Merlini S. \& Cantarella G., 1999. Foredeep geometries at the front of the Apennines in the Ionian Sea (central Mediterranean). Earth Planetary Science Letters, 168, 243-254. Retrieved from http://www.sciencedirect.com/science/journal/00128 21X/168/3-4

Duro A., Piccione V., Scalia C. \& Zampino D., 1996. Precipitazioni e temperature medie mensili in Sicilia relative al sessantennio 1926-1985. Pp. 17-103. In: Guerrini A. (Ed.), Atti del $5^{\circ}$ Workshop del Progetto Strategico "Clima Ambiente e Territorio del Mezzogiorno", I Tomo (a cura di V. Piccione V. e C. Antonelli).

Ferreri D., Bodon M. \& Manganelli G., 2005. Molluschi terrestri della provincia di Lecce. Thalassa Salentina, 28: 31-130.

Gittenberger G. \& Ripken Th.E.J., 1987. The genus Theba (Mollusca: Gastropoda: Helicidae), Systematics and distribution. Zoologische Verhandelingen, 241: 1-59.

Giusti F., 1973. Notulae malacologicae XVIII. I molluschi terrestri e salmastri delle Isole Eolie. Lavori della Società Italiana di Biogeografia, 3: 113-306.

Giusti F., 1976. Notulae Malacologicae, XXIII. I molluschi terrestri, salmastri e di acqua dolce dell'Elba, Giannutri e scogli minori dell'Arcipelago Toscano. Lavori della Società italiana di Biogeografia, 5: 99-355

Giusti F. \& Manganelli G., 1990. Notulae Malacologicae, XLIV. A neotype for Agriolimax caruanae Pollonera 1891 (Pulmonata: Agriolimacidae). Archiv für molluskenkunde, 119: 235-240.

Giusti F., Manganelli G. \& Schembri P.J., 1995. The nonmarine molluscs of the Maltese Islands. Museo Regionale di Scienze Naturali, Torino, Monografie, 15: 1-607. 
Grasso M., 2001. The Apenninic-Maghrebian orogen in southern Italy, Sicily and adjacent areas. In Anatomy of an orogen: the Apennines and adjacent Mediterranean basins. Springer, Dordrecht pp. 255 286.

https://doi.org/10.1007/978-94-015-9829-3_16

Hausdorf B., Bamberger S. \& Walther F., 2020. A Sicilian-Cretan biogeographical disjunction in the land snail genus Cornu (Gastropoda: Helicidae). Zoological Journal of the Linnean Society, 20: 1-16.

IUCN, 2017. The IUCN Red List of Threatened Species. Version 2017-3. http://www.iucnredlist.org (Last access: 01.III.2021).

La Greca M., 1962. Tipi fondamentali di distribuzione geografica degli elementi della fauna Italiana. Archivio Botanico e Biogeografico Italiano, 38: 1230 .

La Rocca R., 2004. Isola delle Femmine un'ipotesi di un insediamento economico polifunzionale ed autosufficiente per la lavorazione del pescato. Sicilia Archeologica, 102: 170-185.

Liberto F., Giglio S., Colomba M.S. \& Sparacio I., 2012. New and little know land snails from Sicily (Mollusca Gastropoda). Biodiversity Journal, 3: 121228.

LIPU (Lega Italiana Protezione Uccelli)1999: Final report 1999. Isola delle Femmine Nature Reserve. Relazione Tecnica dell'Ente Gestore LIPU Onlus, Regione Siciliana-Assessorato Territorio e Ambiente.

LIPU (Lega Italiana Protezione Uccelli) 2003: Final report 2003. Isola delle Femmine Nature Reserve. Relazione Tecnica dell'Ente Gestore LIPU Onlus, Regione Siciliana-Assessorato Territorio e Ambiente.

LIPU (Lega Italiana Protezione Uccelli) 2004: Final report 2004. Isola delle Femmine Nature Reserve. Relazione Tecnica dell'Ente Gestore LIPU Onlus, Regione Siciliana-Assessorato Territorio e Ambiente.

LIPU (Lega Italiana Protezione Uccelli) 2009: Final report 2009. Isola delle Femmine Nature Reserve. Relazione Tecnica dell'Ente Gestore LIPU Onlus, Regione Siciliana-Assessorato Territorio e Ambiente.

LIPU (Lega Italiana Protezione Uccelli) 2011: Final report 2011. Isola delle Femmine Nature Reserve. Relazione Tecnica dell'Ente Gestore LIPU Onlus, Regione Siciliana-Assessorato Territorio e Ambiente.

Lo Brano V.D. \& Sparacio I., 2006. Molluschi terrestri e dulciacquicoli del S.I.C. Rupi di Catalano e Capo Zafferano Sicilia (Gastropoda, Neotaenioglossa, Pomatiasidae, Basommatophora, Stylommatophora). Il Naturalista siciliano, 30: 555-589.

Lo Cascio P. \& Pasta S., 2012. Lampione, a paradigmatic case of Mediterranean island biodiversity. Biodiversity Journal, 3: 311-330.

Lo Cascio P. \& Sciberras A., 2020. "Cold-blooded" travellers around Sicily: how introductions and extinctions have shaped the Recent herpetofauna of Circum-Sicilian and Maltese Islands, pp. 355-390. In: La Mantia T., Badalamenti E., Carapezza A., Lo Cascio P. \& Troia A. (Eds.), Life on islands. Biodiversity in Sicily and surrounding islands. Studies dedicated to Bruno Massa. Edizioni Danaus, Palermo.

Lucido M., 1992. Geomorfologia della piattaforma continentale tra Torre Pozzillo e Torre Mondello (Sicilia nord-occidentale). Il Naturalista siciliano, 16: 91-107.

Maio N., Petraccioli A., Crovato P., Amor N. \& Odierna G., 2013. New faunistic data on Trochoidea (Trochoidea) caroni (Deshayes, 1832) (Gastropoda Pulmonata Hygromiidae). Biodiversity Journal, 4: 483-500.

Manganelli G. \& Giusti F., 1987. Notulae Malacologicae XXXVIII. A new Hygromiidae from the italian Appennines and notes on the genus Cernuella and related taxa (Pulmonata: Helicoidea). Bollettino Malacologico, 23: 327-380.

Manganelli G., Bodon M., Favilli L. \& Giusti F., 1995. Gastropoda Pulmonata. In: Minelli A., Ruffo S. \& La Posta S. (eds.), Checklist delle specie della fauna italiana, 16. Calderini, Bologna, $60 \mathrm{pp}$.

Martínez-Ortí A., 2017. Tudorella panormitana. The IUCN Red List of Threatened Species 2017: e.T75771813A75771853. https://dx.doi.org/10.2305/ IUCN.UK.2017-3.RLTS.T75771813A 757 71853.en. Downloaded on 26 May 2021.

Massa B., Ientile R., Aradis A. \& Surdo S., 2021. One hundred and fifty years of ornithology in Sicily, with an unknown manuscript by Joseph Whitaker. Biodiversity Journal, 12: 27-89 https://doi.org/10.31396/Biodiv.Jour.2021.12.1.27.89

Maurici F. \& Lucido A., 2008. Torre di Fuori di Isola delle Femmine. pp. 176-184 in: Maurici F., Fresina A., Militello F. (a cura di), Le torri nei paesaggi costieri siciliani (secoli XIII-XIX). Torri del Val di Mazara. Centro regionale per l'Inventario, la Catalogazione e la Documentazione dei Beni Culturali e Ambientali, Regione Siciliana, Assessorato ai Beni Culturali, Ambientali e della Pubblica Istruzione, Dipartimento dei Beni culturali, Ambientali e dell'Educazione permanente, Palermo.

Mazzarella S. \& Zanca R., 1985. Il libro delle torri. Sellerio ed., Palermo, 508 pp.

Minelli A., 2012. Dream islands and island dreams. BiodiversityJournal, 3: 267-272.

Monterosato T. Di M., 1892. Molluschi terrestri delle 
isole adiacenti alla Sicilia. Atti della Reale Accademia di Scienze, Lettere ed Arti, $3^{\circ}$ serie, 34 pp.

Muscarella C. \& Baragona A., 2017. The endemic fauna of the sicilian islands. Biodiversity Journal, 8: 249278.

Neubert, E., Seddon, M.B., Allen, D.J., Arrébola, J., Backeljau, T., Balashov, I., Bank, R., Cameron, R., de Frias Martins, A.M., De Mattia, W., Dedov, I., Duda, M., Falkner, G., Falkner, M., Fehér, Z., Gargominy, O., Georgiev, D., Giusti F., Gómez Moliner B.J., Groh K., Ibáñez M., Kappes H., Manganelli, G., MartínezOrtí, A., Nardi, G., Neiber, M.T., Páll-Gergely, B., Parmakelis, A., Prié, V., Reischütz, A., Reischütz, P.L., Rowson, B., Rüetschi, J., Slapnik, R., Son, M., Štamol, V., Teixeira, D., Triantis, K., Vardinoyannis, K., von Proschwitz, T. \& Walther, F. 2019. European Red List of terrestrial molluscs. IUCN: Cambridge, UK and Brussels, Belgium. https://portals.iucn.org/library/node/48439

Nordsieck H., 2002. Contributions to the knowledge of the Delimini (Gastropoda: Stylommatophora: Clausiliidae). Mitteilungen der Dtschen Malakozoologischen Gesellschaft, 67: 27-39.

Parenzan P., 1994. Proposta di codificazione per una gestione informatica dei corotipi W-paleartici con particolare riferimento alla fauna italiana. Entomologica, 28: 93-98.

Pfeiffer K.L., 1931. Die Murellen Westsiziliens. Archiv für Molluskenkunde, 63: 93-116.

Pfenninger M., Vela E., Jesse R., Arantzazu Elejalde M., Liberto F., Magnin F. \& Martínez-Ortí A., 2010. Temporal speciation pattern in the western Mediterranean genus Tudorella P. Fischer, 1885 (Gastropoda, Pomatiidae) supports the Tyrrhenian vicariance hypothesis. Molecular Phylogenetics and Evolution. 54: 427-436.

Prévot V., Jordaens K. \& Backeljau T., 2014. Predominance of a single phylogenetic species in colonization events among a sextet of decollate land snail, Rumina decollata (Mollusca: Pulmonata: Subulinidae), species. Genome 57: 161-167. https://doi.org/10.1139/gen-2013-0187

Pusateri F., 2016. U Pignolu. Via Montalbo: memorie di un rione che fu. Edizioni Danaus, Palermo, 116 pp.

Reise H., Hutchinson J.M.C., Schunack S. \& Schlitt B., 2011. Deroceras panormitanum and congeners from Malta and Sicily, with a redescription of the widespread pest slug as Deroceras invadens n. sp. Folia Malacologica, 19: 201-223.

Reitano A., Liberto F., Giglio S., Grasso R. \& Spena M.T., 2012. Terrestrial molluscs from the R.N.I. "Grotta Conza" (Palermo, Sicily) (Gastropoda Architaenioglossa Pulmonata). Biodiversity Journal, 3: $555-570$

Riggio S. \& Massa B., 1974. Problemi di conservazione della natura in Sicilia. Dati preliminari per un'analisi della degradazione ambientale ed elenco delle aree dell'isola di maggiore interesse naturalistico. Atti del IV Simposio Nazione per la Conservazione della Natura, Bari, 23-28 aprile 1974, 2: 299-425.

Riggio S. \& Raimondo F.M., 1992. Proposta di una riserva costiera per la tutela e la valorizzazione dei biotopi di Isola delle Femmine e di Monte Gallo (Palermo). Quaderni di Botanica ambientale e applicata, 2 (1991): 59-96.

Rivas-Martínez, 2008. Global bioclimatics (Clasificación biclimática de la Tierra) (versión 01-12-2008). www.globalbioclimatics.org (ultimo accesso 17-022021).

Rowson B., 2017. Deroceras panormitanum. The IUCN Red List of Threatened Species 2017: e.T170691 A85576499.

https://dx.doi.org/10.2305/IUCN.UK.20173.RLTS.T170691A85576499.en. Downloaded on 26 May 2021.

Sacchi C.F., 1954. Cyclostoma (Tudorella) sulcatum Drap. in Sicilia occidentale. Doriana, 1: 1-4.

Segre A., 1969. Linee di riva sommerse e morfologia della piattaforma continentale italiana relative alla trasgressione marina versiliana. Quaternaria, 11: 141-154.

Sparacio I., 2020. Brevi osservazioni faunistiche sul commercio dei Molluschi terrestri eduli in Sicilia. Alleryana, 38: 127-133.

Ulzega A., Ozer A., Leone F., Lecca L., Pecorini G., Spano C. \& Cordy J.M., 1980. Excursion INQUA: Table-Ronde Tyrrhénien de Sardaigne (Livret-guide) Cagliari (1980), pp. 1-88.

Ulzega A. \& Ozer A., 1982. Comptes-rendus de l'excursion. Table ronde sur le $\mathrm{T}$ vrrb enien de Sardaign e. INQUA (Avril 1980 ), 110 pp.

Véla E. \& Pavon D., 2012. The vascular flora of Algerian and Tunisian small islands: if ont biodivversity hotspots, at least biodiversity hotchpotchs? Biodiversity Journal, 3: 343-362.

Vigna Taglianti A., Audisio P.A., Belfiore C., Biondi M., Bologna M.A., Carpaneto G.M., De Biase A., De Felici S., Piattella E., Racheli T., Zapparoli M. \& Zoia S., 1993. Riflessioni di gruppo sui corotipi fondamentali della fauna W-paleartica ed in particolare italiana. Lavori della Società Italiana di Biogeografia, 16: 159-179.

Vigna Taglianti A., Audisio P.A., Biondi M., Bologna M.A., Carpaneto G.M., De Biase A., Fattorini S., Piattella E., Sindaco R., Venchi A. \& Zapparoli M., 1999. A proposal for a chorotype classification of the Near East fauna, in the framework of the Western Paleartic region. Lavori della Società Italiana di Biogeografia, 20: 31-59.

Viviano R., Viviano A., Liberto F., Reitano A. \& Sparacio 
I., 2019. A new species of the genus Schileykiella Manganelli, Sparacio et Giusti, 1989 from Sicily (Italy) (Gastropoda Pulmonata Canariellidae). Biodiversity Journal, 10: 71-80.
https://doi.org/10.31396/Biodiv.Jour.2019.10.2.71.80 Wiktor A., 2000. Agriolimacidae (Gastropoda: Pulmonata) - A systematic monograph. Annales Zoologici, 49: 347-590. 